\title{
AUTARCHY, MARKET DisINTEGRATION, AND HEALTH: THE MORTALITY AND NUTRITIONAL CRISIS IN NAZI GERMANY, 1933-1937
}

\author{
JÖRG BATEN \\ ANDREA WAGNER
}

CESIFO WORKING PAPER NO. 800

CATEgory 7: TRAde Policy

OCTOBER 2002

\footnotetext{
An electronic version of the paper may be downloaded

- from the SSRN website: www.SSRN.com

- from the CESifo website: www.CESifo.de
} 


\title{
AUTARCHY, MARKET DisINTEGRATION, AND HEALTH: THE MORTALITY AND NUTRITIONAL CRISIS IN NAZI GERMANY, 1933-1937
}

\begin{abstract}
We compare trends in mortality, nutritional status and food supply to other living standard indicators for the early years of the Nazi period. We find that Germany experienced a substantial increase in mortality rates in most age groups in the mid-1930s, even relative to those of 1932, the worst year of the Great Depression. Expenditures on rearmament grew at the expense of public health measures. Food imports were curtailed, and prices of many agricultural products were controlled. There is ample evidence that this set of economic policies had an adverse effect on the health of the population.
\end{abstract}

JEL Classification: D6, F0, I1, N4, P4.

Jörg Baten

Department of Economics

University of Tübingen

Mohlstr. 36

72074 Tübingen

Germany

joerg.baten@uni-tuebingen.de
Andrea Wagner

Seminar für Sozial- und Wirtschaftsgeschichte

University of Munich

Ludwigstr. 33/III

80539 Munich

Germany

A.Wagner@swg.vwl.uni-muenchen.de 


\section{Introduction}

This study analyses the development of the biological standard of living in Germany under the National Socialist regime before the outbreak of the Second World War. The "biological standard of living" refers to those aspects of a broadly defined living standard that relate to human biology, such as mortality, morbidity, and quality of nutrition as measured by the physical growth of the human organism. These indicators have considerable advantages over the use of GDP per capita as a measure of well-being. ${ }^{1}$ Although real GDP per capita increased rapidly in Nazi Germany, most scholars now agree that it has, in fact, little to say about the actual welfare of the population, inasmuch as most of the additional income generated helped finance state expenditures, including its substantial rearmament programs. In addition, the price and wage controls that were put into effect also invalidate, or at least call into question, most price indices. ${ }^{2}$ Under such circumstances, the concept of the biological standard of living is of particular interest, for the response mechanisms of the human organism do not change when a political and economic regime switches from democracy, with a market economy, to totalitarianism and active state intervention. A rise in mortality is an unequivocal signal that important aspects of the living standard are deteriorating. Longevity, health, and the quality of nutrition are essential components of the utility function. When those components deviate from the standard GDP per capita measure, a more detailed study of human welfare is likely to yield results worthy of note.

The following section surveys indicators of nutrition, mortality, and morbidity. Section 2 examines those causes for the development of these three variables that are not based on the nutrition-mortality relationship, including public health. Section 3 presents evidence that protein deficiency can play a role in mortality even if nutritional circumstances are relatively favourable. Section 4 considers the effects of autarchy and food-pricing regulation policies on regional nutritional status and mortality, and section 5 concludes.

The "early years of the Nazi regime" covers the period between 1933 and 1937, that is, before the incorporation of Austria and prior to the atrocities of the so-called Kristallnacht in 1938. To include that year or the war period would obscure the issue of the impact of persecution and war on living standards. For, even though persecution was intense prior to 1938, its demographic impact was insufficient to account for the decline in population we report below. ${ }^{3}$ 


\section{The development of the biological standard of living}

\section{Mortality and Morbidity}

The crude death rate in Germany, as in Europe declined until 1932. ${ }^{4}$ However, 1932 marked a turning point: German death rates started to increase, whereas the European average continued to decrease. This was even the case relative to such neighbouring countries as the Netherlands and Denmark, with a low-mortality regime. ${ }^{5}$ Between 1932 and 1937 the German population lost 0.4 years of its life expectancy at age 1, while the French gained not less than 1.3 years, the Swedish gained 0.4 years, and the U.S. 0.5 years (calculated from Wagner; 2002, http://demog.berkeley.edu/wilmoth/mortality). ${ }^{6}$

Table 1: Death rates in Germany and Europe (rates per 10,000 inhabitants), 1928-1939

\begin{tabular}{ccccccc}
\hline Years & Germany & $\begin{array}{c}\text { England \& } \\
\text { Wales }\end{array}$ & Netherlands & Denmark & $\begin{array}{c}\text { Index } \\
\text { Europe }\end{array}$ & $\begin{array}{c}\text { Index } \\
\text { Germany }\end{array}$ \\
\hline \multicolumn{5}{c}{ Death Rates per 10,000 Inhabitants } \\
1928 & 116 & 117 & 96 & 110 & 100 & 100 \\
1929 & 126 & 134 & 107 & 112 & 105 & 109 \\
1930 & 110 & 114 & 91 & 108 & 95 & 95 \\
1931 & 112 & 123 & 96 & 114 & 99 & 97 \\
1932 & 108 & 120 & 90 & 110 & 98 & 93 \\
1933 & 112 & 123 & 88 & 106 & 93 & 97 \\
1934 & 109 & 118 & 84 & 104 & 91 & 94 \\
1935 & 118 & 117 & 87 & 111 & 93 & 102 \\
1936 & 118 & 121 & 87 & 110 & 92 & 102 \\
1937 & 117 & 124 & 88 & 108 & 92 & 101 \\
1938 & 117 & 116 & 85 & 103 & 89 & 101 \\
\hline
\end{tabular}

Notes: The European death rate is the unweighted average of the death rates of 20 European countries: Austria, Belgium, Bulgaria, Czechoslovakia, Denmark, Finland, France, Greece, Hungary, Ireland, Italy, Netherlands, Norway, Portugal, Romania, Sweden, Switzerland, England and Wales, Scotland, Yugoslavia. Source: Mitchell (1992), pp. 114-120.

Table 2: Age-specific mortality change (both sexes), Germany, 1932 and 1937

\begin{tabular}{lccc}
\hline Age groups & $\begin{array}{c}1932 \\
\text { (death rate per 1,000 inh.) }\end{array}$ & $\begin{array}{c}1937 \\
\text { (death rate per 1,000 inh.) }\end{array}$ & $\begin{array}{c}\text { Percentage change } \\
1932-1937^{1}\end{array}$ \\
\hline $0-1^{2}$ & 79.18 & 64.36 & -18.7 \\
$1-5$ & 4.50 & 4.65 & 3.3 \\
$5-15$ & 1.40 & 1.59 & 13.6 \\
$15-30$ & 2.66 & 2.61 & -1.9 \\
$30-45$ & 3.98 & 4.02 & 1.0 \\
$45-60$ & 10.39 & 10.54 & 1.4 \\
$60+$ & 53.63 & 55.25 & 3.0 \\
\hline
\end{tabular}

Notes: The borders of Germany changed over the period in question. The data are for the following territories: 1932: German Empire without Saarland), 1937: old territory of the Reich.

${ }^{1}$ Differences in age-specific death rates between 1937 and 1932 in percentages of the death rates in 1932.

${ }^{2}$ Deaths per 1,000 live births.

Sources: Calculated from Statistik des Deutschen Reichs, Vol. 495, Vol. 517, Statistische Beilage Nr. 22 vom 28. Mai 1941 des Reichsgesundheitsblattes, p. 49*. 
The age-specific death rates increased, after having declined markedly in the 1920s, in all age groups except those of infants and of young adults aged 15 to 30 years. Children (age 5-15) suffered the most. In stark contrast, age-specific mortality declined markedly in England of the $1930 \mathrm{~s}$ in almost all age categories.

Table 3: Age-specific mortality rates (both sexes) ${ }^{1}$, England and Wales, 1932 and 1937

\begin{tabular}{|c|c|c|c|}
\hline Age-groups & $\begin{array}{c}1932 \\
\text { (death rate per } 1,000 \text { inh.) }\end{array}$ & $\begin{array}{c}1937 \\
\text { (death rate per } 1,000 \text { inh.) }\end{array}$ & $\begin{array}{c}\text { Percentage change } \\
1932-1937^{2}\end{array}$ \\
\hline $0-4$ & 18,9 & 16,7 & $-11,90$ \\
\hline $5-9$ & 2,1 & 1,9 & $-7,32$ \\
\hline $10-14$ & 1,4 & 1,2 & $-17,86$ \\
\hline $15-19$ & 2,4 & 2,0 & $-17,02$ \\
\hline $20-24$ & 3,0 & 2,7 & $-11,67$ \\
\hline $25-34$ & 3,2 & 2,9 & $-9,38$ \\
\hline $35-44$ & 4,8 & 4,5 & $-6,25$ \\
\hline $45-54$ & 9,4 & 9,1 & $-3,72$ \\
\hline $55-64$ & 20,3 & 20,9 & 3,21 \\
\hline $65-74$ & 50,6 & 49,8 & $-1,48$ \\
\hline $75-84$ & 124,7 & 123,4 & $-1,08$ \\
\hline $85+$ & 271,4 & 277,1 & 2,12 \\
\hline
\end{tabular}

Notes: ${ }^{1}$ Unweighted average of male and female age-specific death rates.

${ }^{2}$ Differences in age-specific crude death rates between 1937 and 1932 in percentages of the death rates in 1932. Source: Calculated from Mitchell (1988), p. 61.

Figure 1: Morbidity rates (per 100,000 inhabitants) from diphtheria, Germany, 19201960

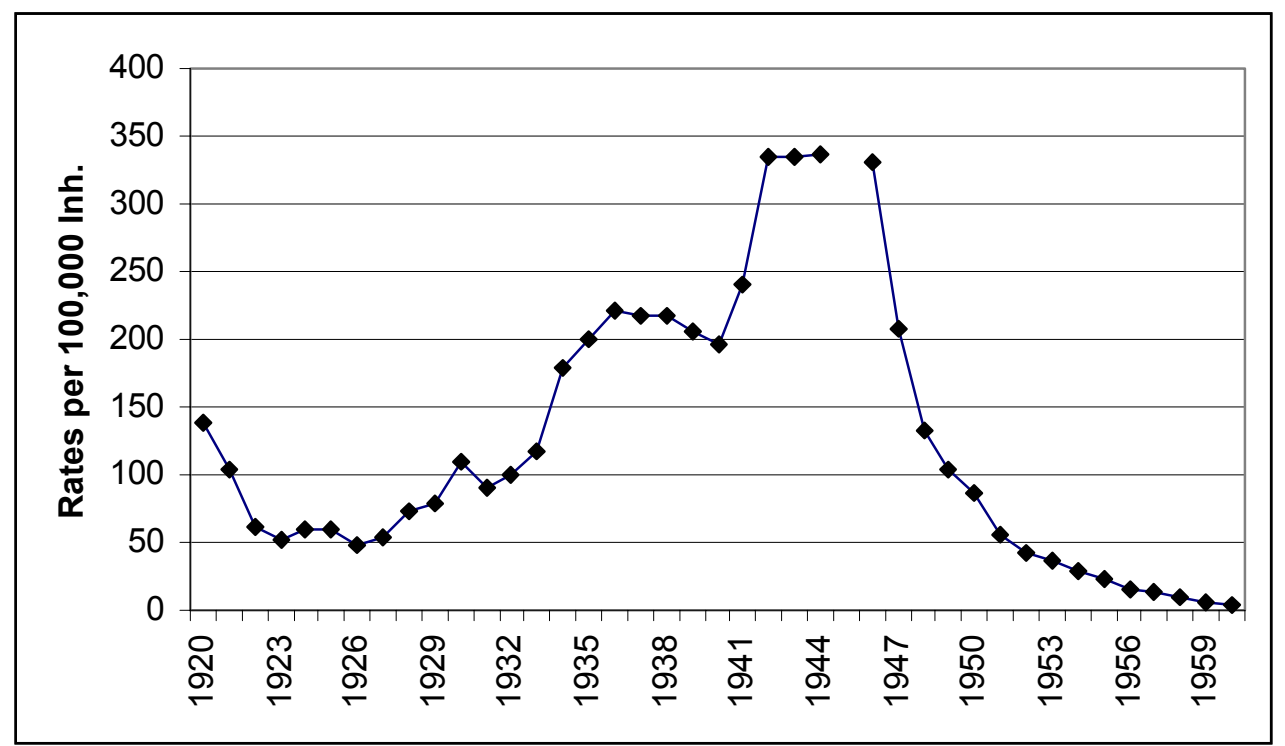

Notes: 1920-1938: German Empire (1925-1934 without Saarland), 1938-1944: territory as of 31. December, 1937, 1946-1960: Federal Republic of Germany (1946 without Lindau, Saarland and Berlin-West, 1947 without Saarland and Berlin-West, 1948 without Saarland).

Source: Statistisches Bundesamt (1972), p. 119.

Furthermore, high morbidity is observable in some contagious disease categories. For instance, morbidity from diphtheria—one of the most serious and widely spread infectious 
diseases of children and young people during the interwar period rose markedly increased after the mid-1920s, doubled again between 1932 and 1937, and reached extremely high levels during the war only to decline rapidly thereafter.

\section{Anthropometric indicators of the quality of nutrition}

Anthropometric indices have been used by economic historians and development economists to study nutritional status (on the Soviet Union see Wheatcroft,1999, pp. 27-60; Komlos, 1999, pp. 71-79; Mironov, 1999, pp. 80-90. On China see Morgan, 1988, pp. 19-20. On the GDR, see Hermanussen, 1997, pp. 135-141. A summary is given in Baten, 2002). Children's heights are particularly sensitive to environmental conditions, as indicated by the decline in height during the hunger years of World War I in the city of Stuttgart

\section{Figure 2: Heights of children in Stuttgart}

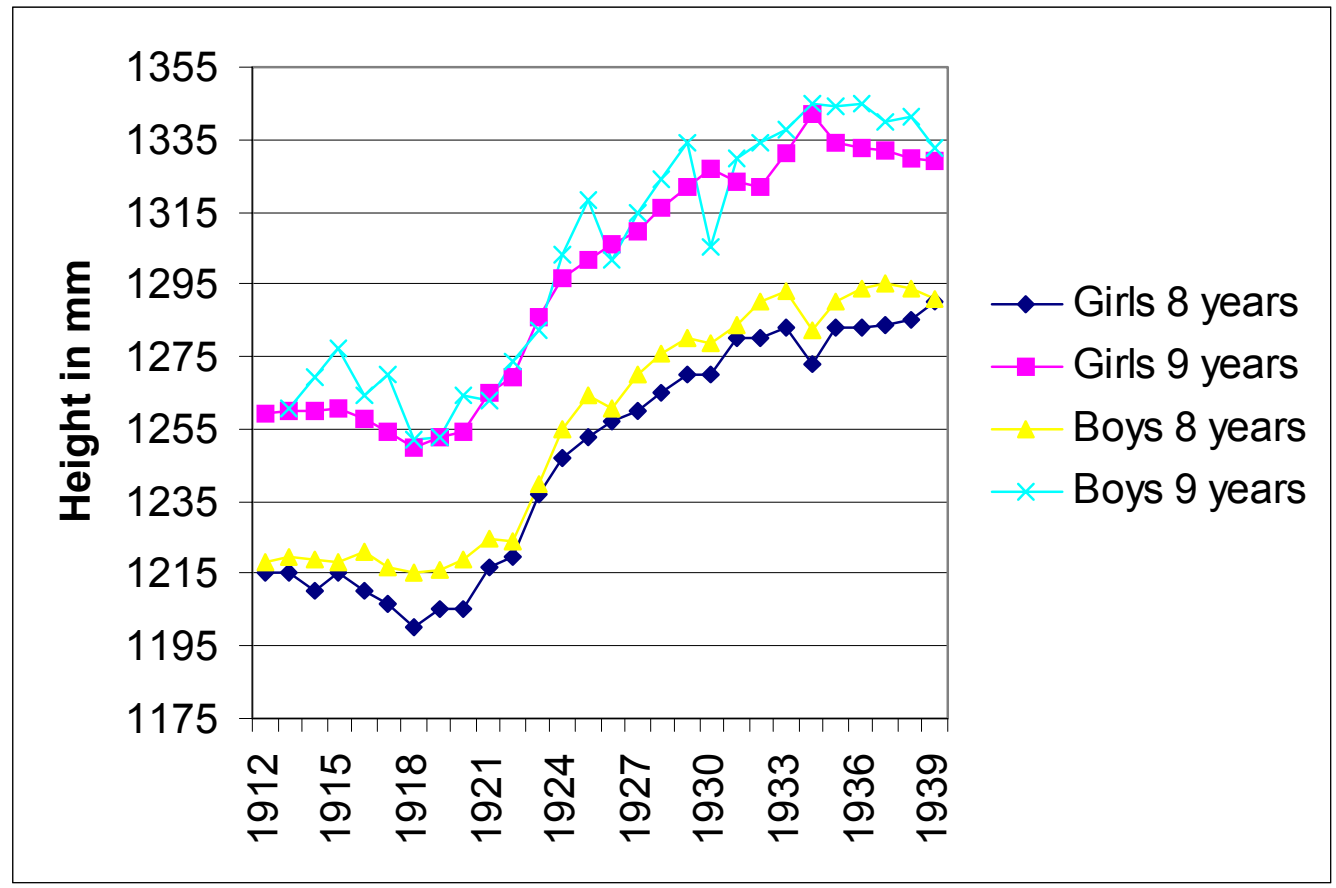

Source: Tanner (1990).

(see also Tanner, 1994, p. 3 and for a detailed time series analysis, see Baten, 2000, pp. 20 22). The increases in physical stature were remarkably large during the 1920s among both boys and girls, but then slowed down, and ceased or even reversed in the 1930s. The only other German series that survives for this period, that for Leipzig, in Saxony, the reversal of the positive secular trend was as dramatic as in Stuttgart. ${ }^{7}$ 
Figure 3: Heights of children in Leipzig (6 years old)

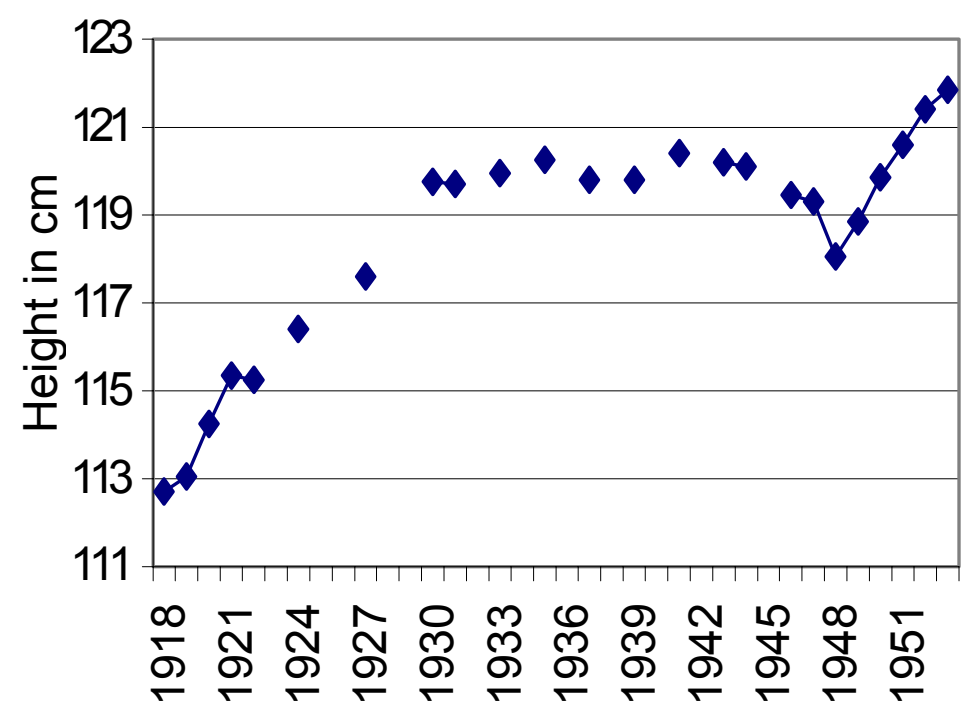

Source: Koch, E. (1953), cited after Marcusson (1962).

Figure 4: Heights of children in Leeds

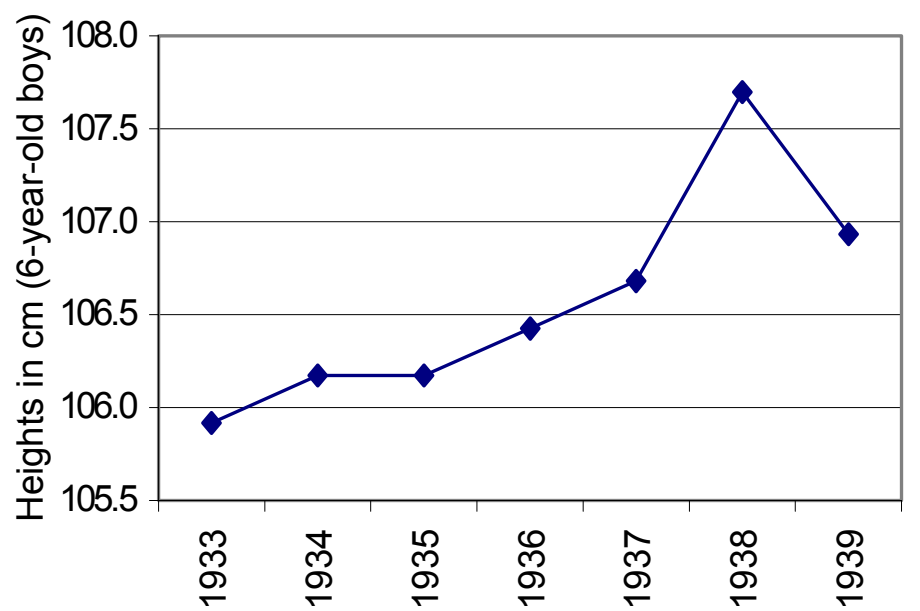

Source: Floud and Harris (1997).

In contrast, heights of other European and American urban populations increased. Leeds, Glasgow, and eight other towns in Great Britain are just some examples (Figure 4). Other similar evidence exist for the Netherlands, and for Pittsburgh, USA, during the Great Depression (Drukker and Tassenaar, 1997, pp. 331-377; Wu, 1992). The Soviet Union might be a counter example, insofar as heights did not increase much there during the 1920s and most of the 1930s. Only during the late 1930s was there a substantial increase in height (Baten, 2002). ${ }^{8}$ Moreover, right after Mussolini had introduced a partial autarchy policy in the 
late 1920s, Italian heights increased much less than, say, Dutch heights (Ibdm.). ${ }^{9}$ In other words, heights were generally increasing vigorously in most countries during the $20^{\text {th }}$ century, due primarily to improvements in food production and in health technology. The stagnation or decline of heights can thus be interpreted as an indication of nutritional problems.

In sum, stagnating heights of schoolchildren, interruption or reversal of the mortality decline, particularly of children, and high morbidity rates from diphtheria, all suggest that the biological standard of living in Germany was either declining, or was at most constant during the first years of Nazi rule. Relative to the achievements of other countries, it most certainly deteriorated. What could have been the factors behind such a development?

\section{Explaining the crisis in the biological living standard}

It is widely assumed that economic growth can improve physical well-being because it enables people to purchase a more nutritious diet, better housing, and more medical care, all of which are important to health. Because the relative deterioration of the biological living standard, accompanied by rising GDP per capita, was due to a decline in disposable income for some segments of the society through rising inequality, the related developments is briefly outlined. We also consider the hypothesis, that a growing physical exertion from intensive work, specifically in the armament industry, damaged workers' health (Hachtmann, 1989, pp. 231-253. See also Geyer, 1989, pp. 392-397. Similarly Mason, 1977, pp. 157, 280-281, 314315. For a differing opinion see Werner, 1983, pp. 21-26).

Persecution for racial and political reasons of important segments of the German society undoubtedly also had a negative impact on living standards in at least two ways: directly, through higher number of deaths from violence or suicides, and indirectly, through a deterioration in the delivery of medical services as Jews were forced to stop practising medicine and teaching in universities. With respect to the whole population, however, these effects may have played a greater role only after 1938.

Another set of determinants may be linked to malnutrition. Contemporaries emphasised the scarcity of food supply in the Third Reich even before World War II, especially the lack of animal proteins and fat, which was often discussed intensively under the terminus technicus Fettluecke (shortage of animal fat) (Gumpert, 1940, pp. 77-80. On the Fettluecke see Corni and Gies, 1997, esp. pp. 309-314). Two related policies of the Third Reich, instituted well before the start of the war, are examined here- the effects of the autarchy policy and the problem of disintegrating food markets due to the newly created price-control system. 
Income and income inequality: the economic recovery in the Third Reich, as measured by GDP, is well documented.

Figure 5: Index of per capita GDP (Index 1928=100), Germany, Great Britain, Netherlands and Denmark, 1928-1939

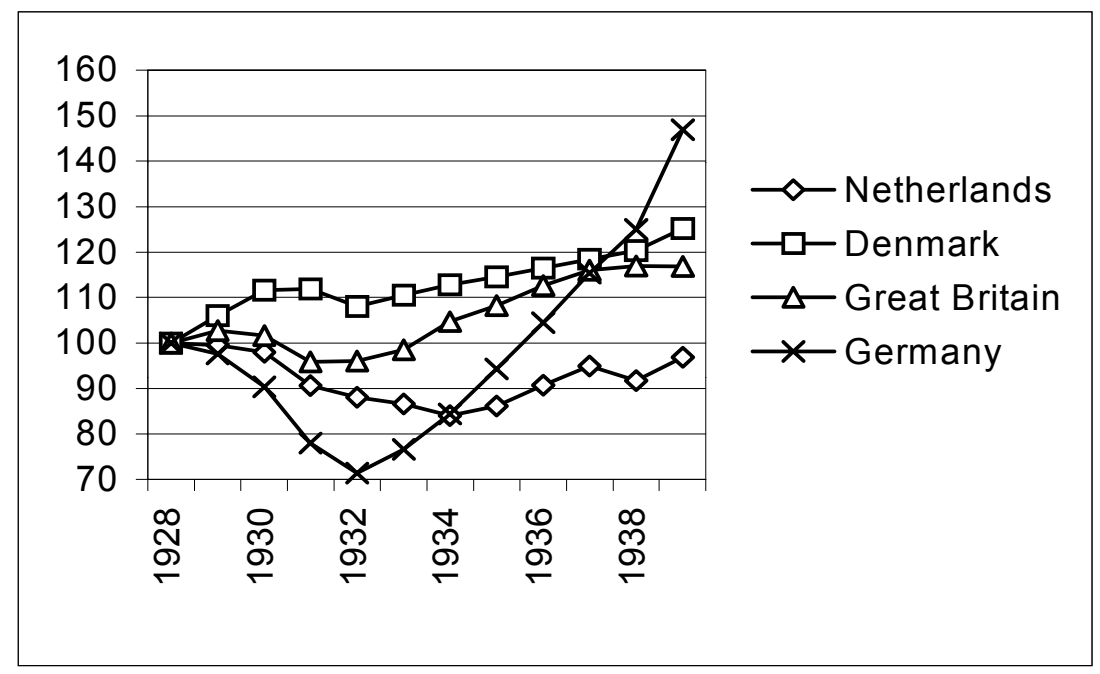

Notes: Germany: 1928-34 without Saarland; 1938-1939 including the new territories.

Source: Maddison (1995), pp.180-183, Ritschl and Spoerer (1997), p. 51

Real GDP grew by some 55\% between 1933 and 1937, and was impressive relative to the Netherlands, even if the recovery was not ahead of that of Great Britain and Denmark. Furthermore, much of the additional output was spent on military equipment, thus, real aggregate private consumption increased by only $19 \%$ during that period of time (calculated from Ritschl and Spoerer, 1997, p. 44, tab.3). Moreover, it seems that the lower classes could not profit from the economic recovery, insofar as personal income inequality widened during the Third Reich (Dumke, 1991, p.128). Labour's share of the total national income decreased, even if compared with 1929, the last pre-crisis year (although during crises wage shares generally increase), in spite of a simultaneously substantial reduction of unemployment (Petzina, 1977, pp. 121-122).

The trend in real wages is still controversial, because price indexes are difficult to interpret. Deterioration in product quality and the loss in utility due to non-availability of some goods pose additional problems of measurement. According to official statistics, real gross wages tended to rise in spite of the official policy that fixed some wages (Tarifloehne), and by 1938, industrial wages recovered to their 1929 level (one of the outstanding boom years under the Weimar regime) (Ibdm. See also Petzina et al., 1978, p. 98 and Siegel, 1982, p. 104, tab. 2.). However, reasonable adjustments to the official figures lead to a more sceptical view of the trends in real income, ${ }^{10}$ and it is most likely that before the war German real weekly net 
wages in industry failed to recover to the level of 1929 (Hachtmann, 1989, p. 158 and p. 159, tab. 14. Overy, 1994, pp. 263-264). In addition, females were actively deterred from participating in the labour force. Given that averages wages probably stagnated, and that the distribution of income probably became more uneven, it is quite possible that the real income of the lower classes declined, which could have contributed to the increase in mortality. On the other hand, the overall increase in total employment had certainly alleviated labour's losses, particularly if the situation is compared with the conditions during the economic crisis of 1930-1933. ${ }^{11}$ The average family had more members participating in the labor force, and fewer needed welfare assistance. The real total household incomes were probably higher in 1937-1938 than at the outset of depression (before the Nazi takeover) even if the real wages of individuals did not recover as unambigously (e.g., Oppenheimer-Bluhm, 1965, pp. 69-70; Kranig, 1992, p. 144. Werner, 1983, p. 19). Thus, the conclusion emerges that private incomes certainly did not increase as much as GDP growth rates would suggest, but there is no strong evidence that income levels of the lower classes declined to such an extent as to account for a deterioration of the biological standard of living.

Growing physical exertion from more intensive work: Increases in weekly wages were generated by longer working hours, not by an increase in the hourly wage rate. By 1938, the number of hours worked per week rose by 3.6 hours (compared with 1933), while the trend during the Weimar Republic had been in the opposite direction (Bry, 1960, p. 48). The increase in working hours was accompanied by greater physical exertion from more intensive work with a negative impact on workers' health. The incidence of industrial accidents also increased by 4\% between 1929 and 1937 (calculated from Hachtmann, 1989, p. 248, tab. 24). In addition, there was an increase of $15 \%$ from 1933 to 1937 in the rate of sickness among health-insured persons, even if sickness rates did not return to the levels of the late 1920s (calculated from Hachtmann, 1989, p. 232, tab. 21). These trends are not surprising, because fluctuations of both morbidity rates (gathered from health insurance companies) and accident rates are generally correlated positively with the movement of the business cycle. ${ }^{12}$ On the other hand, there is considerable evidence that the National Socialist regime undertook several measures to prevent workers from calling in sick or to force them to return to work before they were sufficiently recovered (Hachtmann, 1989, pp. 231-253. Knoedler, 1991, pp.121122). As a result, the published morbidity rates may well understate the morbidity increase. Yet, even with morbidity rates failing to reflect the workers' true health status, the relative deterioration of the biological standard of living cannot be completely explained by worsening working conditions, because the age pattern of the mortality change between 1932 
and 1937 does not fit that explanation. On the one hand, mortality rates of children (ages one to fourteen) increased the most, and that segment of the population was not exposed to physical exertion in the workplace. On the other hand, mortality of people between 15 and 60 years changed very little. Accordingly, other influences that affect peoples' health at younger ages must be taken into consideration.

Medical services: Published statistics on health expenditures and the number of physicians are somewhat inconsistent. ${ }^{13}$ Nevertheless, the available evidence implies that even though medical services (the numbers of hospital beds and physicians per 10,000 inhabitants) had expanded significantly in the second half of the 1920s, they did not improve markedly in the early Nazi years.

Table 4: Medical provision in Germany, 1924-1939

\begin{tabular}{lcccc}
\hline & Hospital Beds & Medical Doctors & Hospital Beds & Medical Doctors \\
\hline & Rates per 10,000 Inhabitants & \multicolumn{2}{c}{ Indexed Figures $1924=100$} \\
1924 & 75.2 & 6.4 & 100 & 100 \\
1925 & 77.5 & & 103 & \\
1926 & 79.6 & & 106 & 108 \\
1927 & 82.2 & 6.9 & 109 & 111 \\
1928 & 85.7 & 7.1 & 114 & 117 \\
1929 & 88.6 & 7.5 & 118 & 116 \\
1930 & 90.9 & 7.4 & 121 & \\
1931 & 91.0 & 7.4 & 121 & \\
1932 & 90.4 & & 120 & 114 \\
1933 & 90.7 & & 121 & 113 \\
1934 & 91.0 & 7.3 & 121 & 114 \\
1935 & 92.0 & 7.2 & 122 & 114 \\
1936 & 92.2 & 7.2 & 123 & 109 \\
1937 & 92.7 & 7.3 & 123 & \\
$1938^{1}$ & 92.9 & 7.3 & 124 & \\
$1939^{1}$ & 87.1 & 7.0 & 116 & \\
\hline
\end{tabular}

Notes: ${ }^{1}$ Territory of the year of 1937. Sources: Statistisches Bundesamt (1972), pp. 124-125

The hospital beds per capita increased but slightly, but the number patients grew twice as fast as the number of available beds (Kater, 1989, p. 43). ${ }^{14}$ Clinic directors as well as professors of medicine lobbied with limited success for extensions of existing hospitals and for the creation of new ones in the later 1930s (Ibdm.).

The ratio of seven medical doctors per 10,000 inhabitants was fairly good by international standards (Süß, 1998b, p. 204), but it was below the peak Weimar level. Immediately after the Nazi takeover, the process of outlawing Jewish doctors began and escalated thereafter (in detail Kater, 1989, pp. 177-221; Kümmel, 1993, pp. 70-74). By the fall of 1938 all Jewish physicians' licences were revoked, affecting about 8,000 to 9,000 doctors, $-16 \%$ of all 
physicians (Kater, 1989, pp. 221; Kümmel, 1993, p. 74). ${ }^{15}$ Furthermore, the quality of medicine as a professional discipline declined through the exclusion of both Jewish medical students and scholars. ${ }^{16}$

Table 5: Health and armament expenditures, Germany, 1928-1938 (million Reichsmarks, constant prices of 1928)

\begin{tabular}{cccc}
\hline Year & $\begin{array}{c}\text { Public Health } \\
\text { Expenditures }\end{array}$ & $\begin{array}{c}\text { Expenditures of } \\
\text { health companies for medical treatments } \\
\text { (incl. drugs) }\end{array}$ & $\begin{array}{c}\text { Armament Expenditures } \\
\text { (without exp. on } \\
\text { transport and }\end{array}$ \\
\hline 1928 & & 670 & 700 \\
1929 & & 728 & \\
1930 & & 727 & \\
1931 & 21 & 664 & \\
1932 & 18 & 580 & 2372 \\
1933 & 17 & & 3800 \\
1934 & 47 & 599 & 6800 \\
1935 & 57 & 673 & 12844 \\
1936 & 50 & 695 & 13657 \\
1937 & 52 & 718 & 21390 \\
1938 & & 766 & \\
\hline
\end{tabular}

Source: Estimated from Süß (1998b) pp. 539-541 and Overy (1994), p. 48.

Table 5 presents health expenditures of the state and of health insurance companies in Germany between 1932 and 1938. Real payments for medical treatments by social insurance (Krankenkassen) recovered after the Depression, but not fully to their 1929 level, as has been pointed out by Suess (1998a). ${ }^{17}$ Tennstedt (1976) reports that the number of people receiving voluntary health services, such as recuperation measures and sickness prevention decreased by $70 \%$ between 1930 and $1937 .^{18}$

Public health measures: Formal public health services were increased during the 1920s, but were substantially cut back during the economic crisis until 1934 (Table 5) (Sachße and Tennstedt, 1992, p. 166).

Due to the creation of a state-centralised system of public health departments, those expenses more than tripled in the following two years to 57 million Reichsmark ( Suess, 1998b, p. 48), but they accounted for only an inconsequential share of total health expenditures, and for only $0.4 \%$ of the military expenditure in 1937 . Therefore, only a very small part of the additional aggregate income was used for investments in the public health sector. Altogether it appears that medical services did not deteriorate dramatically between 1933 and 1937, even if it is possible to identify some adverse developments. Nonetheless, it seems unlikely that the rise in 
mortality, particularly that of children, was caused by changes in the delivery of medical services to the population.

The Nazi population policy focused on the prevention of infant mortality, mainly through a wider public education of child care and the promotion of breastfeeding and healthy nutrition (Seidlmayer, 1937; Naumann, 1941. For an overview about welfare for small children and mothers see Pine, 1997, pp. 23-38). Totalitarian regimes are relatively efficient at reducing infant mortality, considering that the first 12 months are mainly influenced by parental behaviour and - compared with the mortality of older children — not linked as much to the availability of nutritional resources. Behaviour can be influenced by propaganda, at which totalitarian regimes are often particularly skilled (Baten, 2002). ${ }^{19}$ In addition, new and improved public health measures benefited infants. The number of maternity, child, and infant welfare centres increased from 6,617 in 1928 to 14,876 in 1937 . Almost 70\% of all live births were monitored by those institutions in 1937 (Sachße and Tennstedt, 1992, pp. 166-168). Infant mortality decreased markedly by $18.7 \%$ between 1932 and 1937 (see table 2). ${ }^{20}$ Yet, in spite of those considerable efforts to improve infant survival, it did not do so any faster than in most other European countries during the same period of time (see Mitchell, 1992, pp. 119-120). Contemporaries speculated in that the increase in fertility in the first years of Nazi rule could have led to higher infant and maternal mortality. Thus the impact of fertility increase on mortality is also included in our regression analysis below.

Much effort during the Nazi years was also directed towards older children, but it seems to have had only limited success. ${ }^{21}$ Public health policy failed in the fight against diphtheria, the most important single cause of death among children between the ages of one and fifteen. More children died from that disease (16\%) than from tuberculosis (10\%), pneumonia (14\%), or accidents (11\%) (calculated from sources from Table 6).

As mentioned above, morbidity rates from diphtheria increased after 1925 in Germany, as in many other countries. However, German health authorities introduced vaccination programmes slowly compared to international standards (for the following see Suess 1998b, pp. 241-250). Until 1939-1940 German health authorities still favoured older forms of state intervention, relying on isolation and disinfection. After 1939, immunisation programmes were conducted at the local level, and only in the fall of 1941 did the Reich ministry of the interior finally recommend that communities experiencing diphtheria epidemics carry out vaccination programmes. In contrast, countries such as the United States had introduced already in the 1930s immunisation programmes with a new diphtheria toxoid that was available in Germany by $1936 .{ }^{22}$ However, it took another few years for the vaccine to be 
administered on a broad scale. As a result, German diphtheria death rates increased from 6.1 in 1932 to 9.6 per 100,000 inhabitants in 1937, whereas they dropped from 4.4 to 2.0 in the United States (see table 7 and U.S. Department of Commerce, 1975, p.58). ${ }^{23}$

\section{Did malnutrition play a role in the mortality trends?}

Infectious diseases such as tuberculosis, respiratory infections (bacterial and viral), measles, whooping cough, bacterial diarrhea, and some parasitic diseases are definitely influenced by the nutritional status (Lunn, 1991, p. 137). Diphtheria and influenza are at least partly affected by nutrition, and mortality from respiratory diseases (such as pneumonia and bronchitis) and diseases of the digestive system are most likely linked to the nutritional status. In contrast, mortality from diseases such as tetanus, malaria, smallpox, and yellow fever are independent of nutritional status as are deaths due to non-communicable diseases, such as cancer, as well as from violence. Table 6 presents differences in percentage points in cause-specific, agestandardised mortality rates in Germany in three time periods: 1925-1932, 1932-1935, and 1935-1937. ${ }^{24}$ Positive values indicate that cause-specific mortality increased. During the Weimar period (1925-1932) all causes of death that were certainly or possibly associated with the nutritional status declined. By contrast, mortality from most of those causes, such as acute childhood infections, influenza, and pneumonia, increased in the second half of the 1930s, compared to 1932 . Only tuberculosis continued to decline in the 1930 s, probably due to the implementation of mass X-ray screening, which helped identify tuberculosis at an early stage, ${ }^{25}$ but that decline was slower than it had been from 1925 to 1932.

The overall increase in infectious diseases in the 1930s is unexpected, inasmuch as the model of the epidemiological transition implies that during the 1930s mortality caused by degenerative diseases would increase, but mortality from communicable diseases would decline. $^{26}$ 
Table 6: Differences in cause-specific, age-standardised mortality (SMR) in Germany (differences of percentage points, per 10,000 inhabitants), 1925-32, 1932-35, 1932-37 ${ }^{1}$

\begin{tabular}{|c|c|c|c|}
\hline Causes of death & $1925-32$ & $1932-35$ & 1932-37 \\
\hline Diseases of the newborn and malformations ${ }^{2}$ & 3.4 & -1.1 & -3.5 \\
\hline Childbirth $^{3}$ & 0.3 & -0.4 & -1.0 \\
\hline Acute childhood infections ${ }^{4}$ & -1.1 & 0.5 & 0.3 \\
\hline Influenza & -0.7 & 1.4 & 0.8 \\
\hline Tuberculosis (all forms) & -3.2 & -0.2 & -0.7 \\
\hline Other infectious diseases ${ }^{5}$ & -0.8 & 0.2 & 0.1 \\
\hline Pneumonia & -2.2 & 1.1 & 0.4 \\
\hline Other respiratory diseases & -0.9 & 0.0 & -0.3 \\
\hline Circulatory system & -3.0 & 1.3 & 1.5 \\
\hline Central nerve system and sense organs ${ }^{6}$ & 0.8 & -1.0 & -1.4 \\
\hline Digestive system & -2.1 & -0.4 & -0.4 \\
\hline Cancer and other tumors & 1.3 & 0.2 & 0.2 \\
\hline Suicide & 0.3 & -0.2 & -0.1 \\
\hline Accidents $^{7}$ & -0.4 & 0.6 & 1.0 \\
\hline Other causes $^{8}$ & -6.2 & -0.3 & -1.5 \\
\hline Ill-defined diseases & 1.5 & -0.3 & -0.6 \\
\hline
\end{tabular}

Notes: ${ }^{1}$ SMR: German population in 1925. Causes of death classification changed in 1932.

${ }^{2}$ Deaths per 1.000 live births. 1925: Weakness of life and congenital malformations; 1932-1937: Weakness of life, premature birth, congenital defects, other diseases of infants under three months and congenital malformations in the first year of life.

${ }^{3}$ 1925: Puerperal fever and other diseases of childbirth; 1932-1937: Diseases of pregnancy. childbirth and puerperal state.

${ }^{4}$ 1925: Measles and rubella, whooping cough and croup, diphtheria and scarlet fever; 1932-1937: Measles, whooping cough, diphtheria and scarlet fever.

${ }^{5}$ Infectious and parasitic diseases without acute childhood infections, influenza and tuberculosis.

${ }^{6}$ 1925: Stroke and other diseases of the nervous system; 1925-1937 including diseases of the sense organs.

7 1925: Accidents and other deaths from violence (without suicide and homicide).

${ }^{8}$ 1925: Old age, diseases of the genito-urinary system and other stated causes of death; 1932-1937: Old age, diseases of the genito-urinary system, diseases of blood and blood-forming organs, chronic poisoning, rheumatism, diseases of nutrition and endocrine glands and other general diseases, diseases of the bones and organs of locomotion, diseases of skin and cellular tissue and other stated causes of death.

Source: Calculated from Statistische Sonderbeilage zur Nr. 25 vom 22. Juni 1927 des Reichs-Gesundheitsblattes; zur Nr. 11 vom 11. März 1936 des Reichs-Gesundheitsblattes; Nr. 30 vom 26. Juli 1939 des Reichs-

Gesundheitsblattes; Nr. 22 vom 28. Mai 1941 des Reichsgesundheitsblattes.

Table 7 presents the percentage differences in cause-specific death rates between 1932 and 1937 in Germany and England. ${ }^{27}$ Column 4 illustrates the disparity of the mortality change between the two countries. The German development was less favourable in many nutritionrelated diseases, such as acute childhood infections and influenza, as well as diseases of the respiratory system including pneumonia and bronchitis. However, the gap between German and English mortality changes was less marked for such degenerative diseases as cancer or diseases of the circulatory system. Thus, between 1932 and 1937, Germany experienced greater increases in mortality from nutrition-related diseases than England, even though some nutrition-related mortality increased there as well. ${ }^{28}$ 
Table 7: Change in cause-specific mortality, England \& Wales and Germany, 1932 and 1937 (\% increase of death rates per 10,000 Inhabitants)

\begin{tabular}{lrrr}
\hline 1 & 2 & 3 & 4 \\
Causes of deaths & England & Germany & Difference \\
\hline Infectious and parasitic diseases & -8.5 & 8.4 & 17.1 \\
$\quad$ inclusively measles & -69.4 & -15.8 & 53.6 \\
$\quad$ inclusively scarlet fever & -30.8 & 88.4 & 119.2 \\
$\quad$ inclusively whooping cough & -41.9 & -0.3 & 41.6 \\
$\quad$ inclusively diphtheria & 24.1 & 56.4 & 32.3 \\
$\quad$ inclusively influenza & 38.8 & 65.5 & 26.7 \\
$\quad$ inclusively tuberculosis & -17.0 & -7.8 & 9.2 \\
Cancer and other tumors & 7.2 & 11.0 & 3.8 \\
Rheumatism, diseases of nutrition and endocrine glands & 8.8 & 21.1 & 12.3 \\
and other general diseases & & & \\
Diseases of the blood and blood-forming organs & -1.7 & 2.4 & 4.1 \\
Diseases of the nervous system and sense organs & -3.3 & 1.2 & 4.5 \\
Diseases of the circulatory system & 20.6 & 23.6 & 3.0 \\
Diseases of the respiratory system & -6.6 & 13.6 & 20.2 \\
$\quad$ inclusively bronchitis & & & 21.6 \\
$\quad$ inclusively pneumonia & -13.8 & 7.8 & 21.4 \\
Diseases of the digestive system & -2.0 & 19.4 & 12.7 \\
Deaths from violence & -7.9 & 4.8 & 11.1 \\
\hline Nor Disse & 2.2 & 13.3 &
\end{tabular}

Notes: Disease that are at least variably nutrition-sensitive are given in italics. Column 2 and 3: Differences in cause-specific crude death rates between 1937 and 1932 in percentages of the death rates in 1932. Column 4: Differences between column 2 and 3. Source: See table 6 and The Registrar-General's (1940), pp. 25-38. We thank Bernard Harris for generously providing the English statistics.

In sum, mortality from several infectious childhood diseases and from pneumonia rose in Germany in the 1930s, whereas those causes of death had been substantially reduced from 1925 to 1932 . Because most of those diseases are related to protein deficiency at least to some extent, the inference is warranted that nutrition may well have played a role in the deteriorating mortality regime in Germany of the 1930s.

\section{The impact of autarchy and price control on regional mortality}

What could have influenced the quality of nutrition sufficiently to affect mortality rates, if real family incomes did not decline? One important aspect of nutrient quality is the amount of proteins available, as these are essential for the proper functioning of the immune system and all living cells, even if temporary decrease in protein intake does not have immediate deleterious consequences. ${ }^{29}$ One should also consider the regional differences in consumption patterns particularly those caused by the Nazi autarchy policy. 
Currency reserves were extremely limited during the depression, and the high-tariff policies of many countries, but especially the overvaluation of the German Mark not only prevented Germany from increasing its exports but also greatly limited its imports. ${ }^{30}$ However, the balance-of-payment argument is only partially valid, insofar as Germany did import raw materials for rearmament. The currency used to buy Swedish iron could have just as easily bought Danish cattle. In addition, the balance-of-payment was only one of the two reasons for the switch to an autarchy policy. The other one was motivated by military purposes. During WW I the German population had gone from hunger to revolution - and that dramatic experience had to be avoided at any cost. So food imports did not stop in the 1930s, but their protein content was less than in the 1920s. In the 1930s more grain was imported from southeastern Europe, but food imports did not increase as much it would have been possible and expected as GDP increased - balance of payments notwithstanding — because of the import substitution from food to raw materials for rearmament (Hoffmann, 1965, pp. 524$525)$.

The impact of the autarchy policy on the coastal areas was dramatic.

Table 8: Beef „production“1929-36 in German regions (slaughtered animals, changes in \%)

\begin{tabular}{lll}
\hline & Interior & Coast \\
\hline Rural & $+0,8$ Bavaria & $-36,8$ Schleswig-H. \\
& $+2,9$ Wuerttemberg & $-65,0$ Mecklenburg \\
& $+6,7$ Saxonia & \\
Urban & $-1,4$ Berlin & $-21,4$ Hamburg \\
& & $-42,4$ Bremen \\
& & $-76,3$ Luebeck \\
\hline
\end{tabular}

Source: Statistisches Jahrbuch, various issues.

In Schleswig-Holstein and Mecklenburg 37\% and 65\% fewer cattle were slaughtered in 1936 than in 1929, because of the limitation on imports of live cattle. The trends were similar in the port cities. In contrast, cattle slaughtering increased in the more agricultural regions of the South and Southeast, and remained constant in Berlin, indicating the regional diversity of the autarchy policy. We are focusing on beef as a protein-intake indicator not because of its nutritional value but because of the availability of data. We would have preferred to include pork and milk consumption, but the lack of extant statistics prevents us from doing so. The Nazis were eager to keep prices artificially low for milk and bread (and to some extent for pork), but they were much less concerned about beef, and consequently beef prices were set by market forces. Given the possibility of substituting among food products, the high beef prices also imply that other meat and dairy products were scarce. The controlled low prices 
led to decreasing supply, as many farmers who previously concentrated on dairying switched to beef production, especially in the regions with high beef prices.

The amount of beef that an unskilled wage earner could buy was, indeed, declining sharply in the Northwest by $8 \%$.

Figure 6: Changes of purchasing power of beef between 1933 and 1936 (in \%)

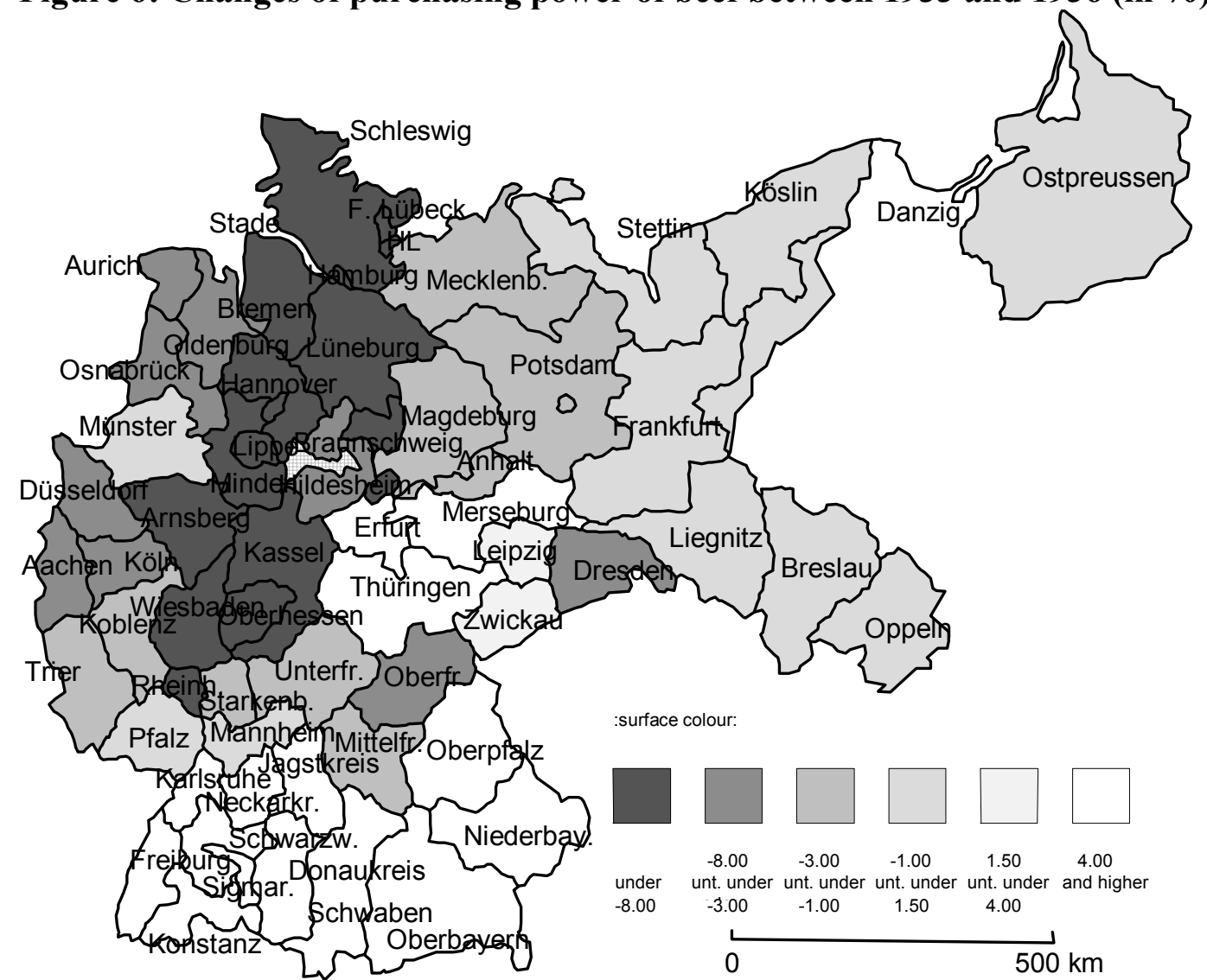

Source: Statistisches Jahrbuch für das Deutsche Reich (various issues).

The dairy region of Muensterland was affected less, and the regions along the Dutch border were also doing better. Nonetheless, the whole Northwest faced worse conditions than the South and Thuringia. The East took an intermediate position. Danish cattle and Dutch meat were definitely in short supply in the Northwest. ${ }^{31}$ If we compare this indicator of protein shortage with the regional differences in mortality increase, the parallel is striking (figure 6 and 7). Potsdam, the region around Berlin, and the Saxon area of Zwickau did somewhat worse than expected on the basis of our protein-shortage indicator.

The second source of regional inequality was the introduction of regulation of the price of food. The policy posed a dilemma for the Nazi government because many farmers had been strong supporters of the NS movement from the very beginning, and as a result they expected high prices for their products (Corni and Gies, 1997, pp. 309-314). At the same time, Hitler feared dissatisfaction from people living in industrial cities that could have threatened the 
smooth functioning of the armament industries. The solution was to regulate prices and to reduce the profits of the food merchants which required an enormous bureaucratic effort. Anti-Semitic motivations further reinforced that policy approach.

Figure 7: Changes of of mortality rates between 1932 and 1936 (in \%)

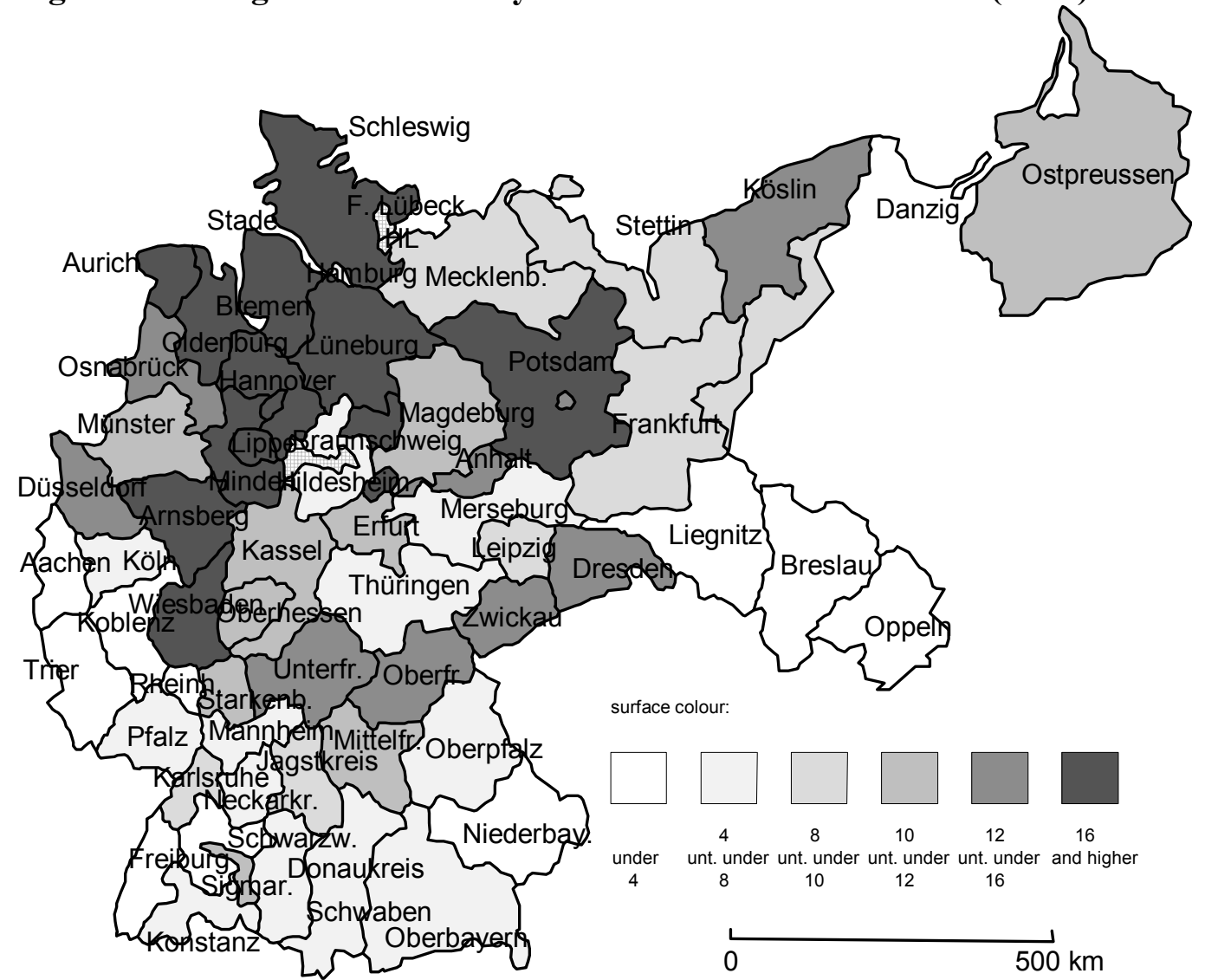

Source: Statistisches Jahrbuch für das Deutsche Reich (various issues). We thank M. Haines for sharing his data with us.

The result was, of course, a less-efficient food distribution system. If profits are artificially reduced, more and more firms move out of the trade, hindering the interregional exchange of products.

As a consequence, the integration of food markets between rural and urban areas was breaking down, and farmers had an incentive to consume more foodstuffs within their own households. This was especially the case with perishables. Based on evidence from Munich and Dresden, the result was a diminution in urban meat consumption, which is mirrored by the increase in mortality.

According to Prussian data, larger cities, with 100,000 and more inhabitants, experienced a more significant increase in mortality, than smaller ones, and small towns (15-30,000 inhabitants) even had declining mortality experience. It may well be that small towns had better access to food on account of their rural surroundings. 
Figure 8: Meat consumption in Germany and in two cities

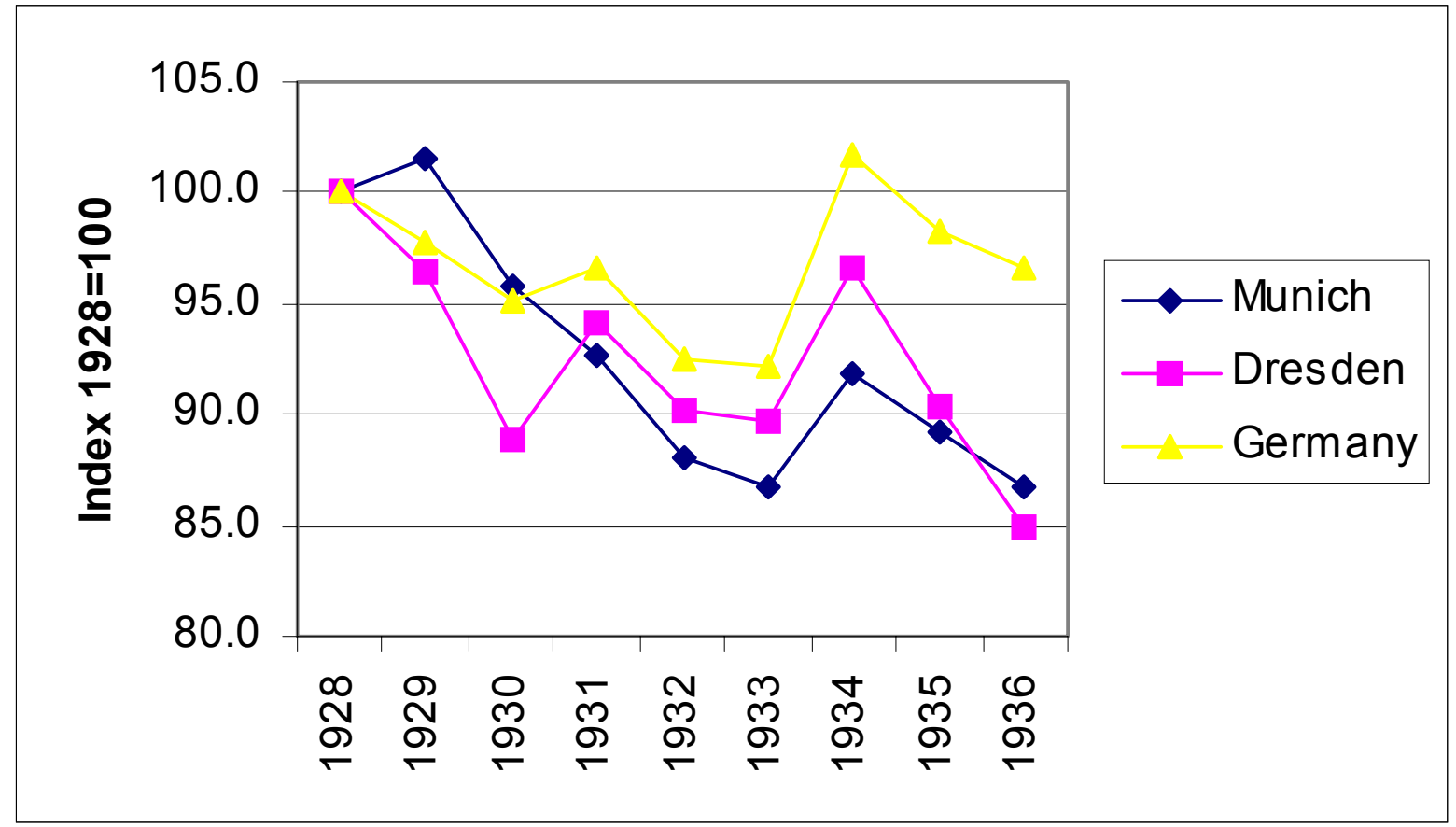

Sources: Vierteljahreshefte zur Statistik des Deutschen Reiches (1938); Stat. Jahrbücher of various German cities.

Figure 9: Mortality increase in Prussian cities (adjusted increase, 1932-38)

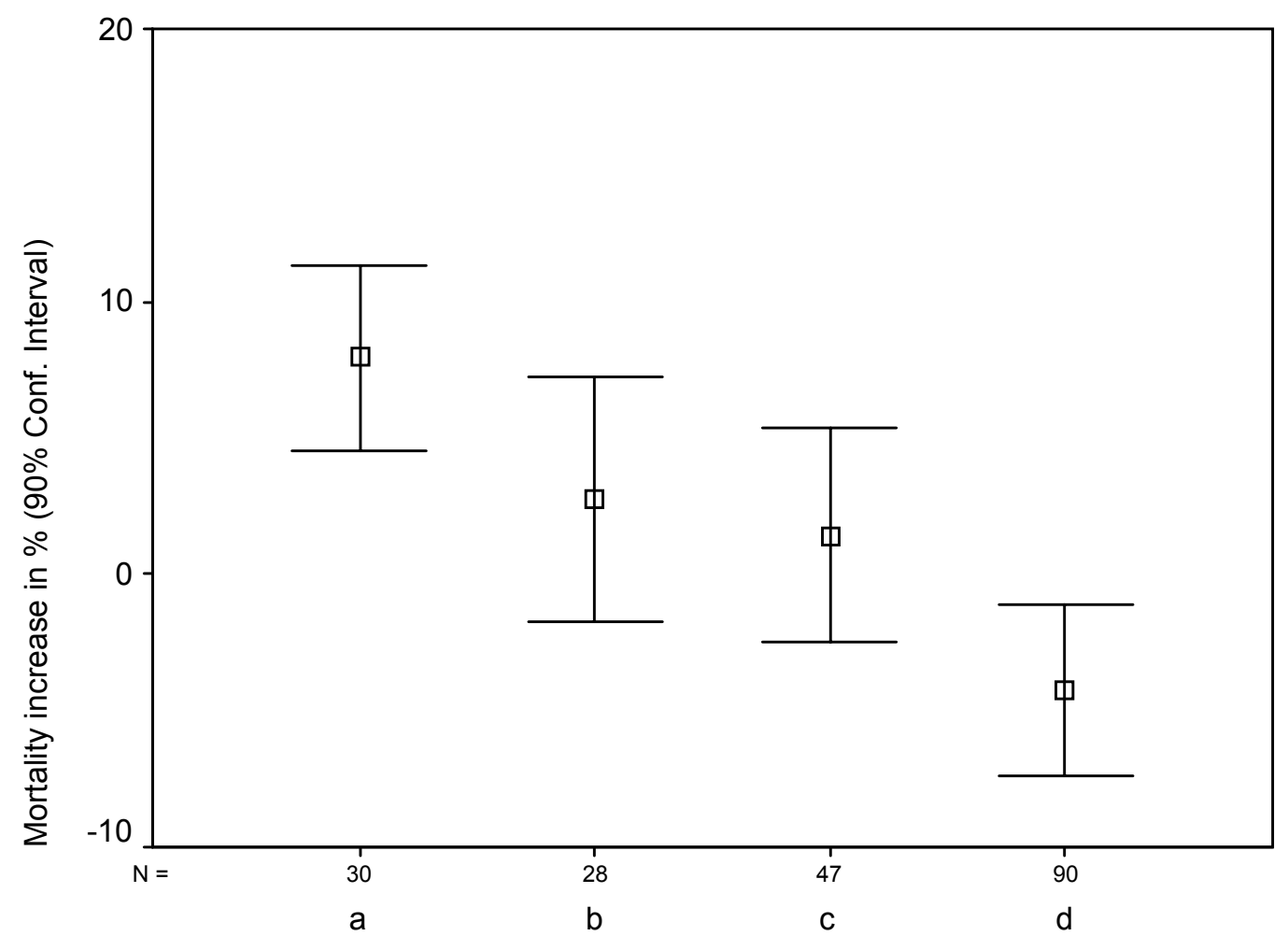

City size

City size: $a=100,000$ and more $, b=50-100,000, c=30-50,000, d=15-30,000$ inhabitants)

Sources: Calculated from Statistische Sonderbeilage zur Nr. 11 vom 11. März 1936 des ReichsGesundheitsblattes; Nr. 4 vom 26. Januar 1941 des Reichs-Gesundheitsblattes. 
However, the decline in meat consumption was by no means large compared to the 1928 level. Several considerations question the validity of these official statistics. Firstly, we do not know the accuracy of these politically sensitive data in a totalitarian state that claimed legitimacy through raising welfare (Von der Lippe, 1996). The numerous reports about empty shops certainly call into question their reliability. ${ }^{32}$ In addition, a study by the US ministry of agriculture concluded that meat consumption of German workers decreased by $17 \%$ between 1927 and 1937, milk consumption by $21 \%$, and egg consumption by $46 \%$. At the same time, the much debated "Fettluecke" (fat shortage) resulted in a decline of fat consumption of "only" 7\% (Franklin, 1940). (2) Secondly, even if the official figures were correct: unequal distribution of nutritional resources would remain a problem. How much was locally consumed by farmers, who had a very favourable diet anyway? Hence, the national average is not very informative in this respect. ${ }^{33}$ (3) Thirdly, the structure of consumption was much different after 1933. Proteins were clearly redistributed in favour of the military and probably to special national socialist institutions such as the Reichsarbeitsdienst (obligatory labour camps for young adults). More meat was served in restaurants than in private households, which was probably not beneficial for children's consumption (Bundesarchiv Berlin NS 5 VI 8983 pp. 51, 52). It is not surprising that price controls brought about black-market activities. Contemporary reports often mentioned the unwillingness of farmers to deliver fat and proteinrich products to the state food-collecting institutions. ${ }^{34}$ The removal of Jewish cattle traders had a further damaging impact on market structure. Police and administration reports concerning the Bavarian district of Ebermannstadt make clear the nature of black-market activities (Broszat and Froehlich, 1979). In September 1935, for example, the district administration reports that after the Milchversorgungsverband (milk-supply union) fixed the quota, there was "a great dissatisfaction among farmers. Food prices have risen.... The maximum price for cattle sales has often been exceeded and some farmers have not delivered the milk fat to the Rahmsammelstellen (milk-fat collection places), but instead they produced butter on their own and sold it on the black market" (p. 164). ${ }^{35}$ One year later, in June 1936, the local police reported that "prices for cattle, butter, and eggs are very high at the moment. Some of the farmers are very unhappy about the laws on butter, milk, and eggs" (p. 172). In September, another police station noted that "farmers unwilling to deliver their milk to the dairy farm (Molkerei) Plunck as the price of 12 Pfennig is too low" (p.177, "Plunck" is the name of the dairy farm). In November, the district administration recorded that "the milk delivery duty is still meeting with difficulties in some communities. Again and again, people try to produce butter illegally and sell it. The police is instructed to apply more rigid 
(verschärfte) controls and to act without consideration (rücksichtslos). During a control at the railway station in the village of Unterleinleiter a few days ago, no less than 193 pounds of butter was confiscated from four female traders, who planned to transport it" (p.178). These numerous black-market activities demonstrate how deep-reaching were the effects of the market disintegration brought about by the Nazi government's price-regulation policy.

We next test the impact of several variables on mortality patterns in 192 Prussian cities for 1932 and 1938, and on 66 German counties (Regierungsbezirke) for 1932 and 1936 using regression analyses.

Table 9: Regressions: Determinants of mortality increase in Prussian cities, 1932-38

\begin{tabular}{lcc}
\hline Regressions & Total mortality & Pneumonia mortality \\
\hline Import region & 5.76 & 17.24 \\
City size $>100000$ & $(0.01)$ & $(0.06)$ \\
City size 50-100000 & 17.69 & \\
& $(0.00)$ & \\
City size 30-50000 & 10.5 & \\
& $(0.00)$ & 0.74 \\
Industry \% & 7.4 & $(0.09)$ \\
& $(0.00)$ & \\
Jewish \% & 0.59 & 0.38 \\
& $(0.00)$ & $(0.32)$ \\
Older than 65 & -3.32 & -10.21 \\
& $(0.03)$ & $(0.54)$ \\
Constant & 0.32 & 0.04 \\
& $(0.00)$ & 192 \\
Adj. Rsq. & -32.38 & \\
$\mathrm{~N}$ & $(0.00)$ & \\
\hline
\end{tabular}

p-values in parentheses. Sources: Statistik des Deutschen Reiches (various issues). There is no strong multicollinearity among the variables (according to the multicollearity indicator "Varaince Inflation Factor").

We can control for the increase in the share of old people to control for an age-structure effect in the cities. This variable does have an influence on total mortality (column 1) but not on pneumonia mortality (column 2). The dummy variable for "import region" (coastal regions plus regions along the lower banks of the Rhine, Elbe, and Oder rivers) has a strong effect, even after controlling for age structure. The mortality increase was almost $6 \%$ higher there. City size was an independent albeit important factor. Again, the largest cities suffered most, experiencing an increase $18 \%$ higher than the constant representing the small towns. The occupational share in industry has an additional influence that is economically important. More administrative or partially agricultural towns were doing better during that period, with industrial cities suffering more. We inserted the Jewish-population share to control for 
potential direct effects of persecution. This variable turns out to be negative, contrary to expectations. It is unclear why a higher Jewish share could have reduced mortality, but we can conclude that the rise in mortality of the population was not caused by the persecution. The goodness-of-fit measure adjusted $\mathrm{R}^{2}$ indicates that the percentage of explained variance is a remarkable $(41 \%)$. It is much higher than in the second regression that considers pneumoniamortality increases separately. However, pneumonia was also much more influential in the import region and in industrial towns. The Jewish share and the city-size dummies are insignificant.

The non-Prussian South was included in the county-level regressions.

Table 10: Regressions: Determinants of county level mortality increases (Regierungsbezirke 1932-36)

\begin{tabular}{lcc}
\hline & $(1)$ & $(2)$ \\
\hline Import region (Dummy) & 4.05 & \\
Purchasing power of beef & $(0.00)$ & -0.51 \\
(increase in \%) & & $(0.00)$ \\
Fertility change \% & 0.31 & 0.27 \\
& $(0.00)$ & $(0.00)$ \\
Unemployment 1933 in \% & -0.13 & -0.26 \\
& $(0.00)$ & $(0.02)$ \\
Jewish \% & 0.02 & -0.16 \\
& $(0.83)$ & $(0.15)$ \\
Constant & 2.42 & 6.88 \\
& $(0.26)$ & $(0.00)$ \\
Adj. Rsq. & 0.37 & 0.51 \\
N & 66 & 66 \\
\hline p-values in parentheses. Sources: Statistik des Deutschen Reiches (various issues). There are no strong \\
multicollinearities (according to VIF).
\end{tabular}

As an alternative to the import-region dummy we inserted the purchasing power of beef (a protein-availability indicator) in column 2 . This model explains even more of the interregional variation of the mortality increase than column 1 , with an adjusted $\mathrm{R}^{2}$ of 0.51 . The Jewish share is insignificant. Increasing crude birth rate contributed in fact to the mortality upsurge as contemporaries had argued - but it did not affect the significance of the import region or the beef-purchasing power variable. The unemployment share in 1933 denotes particular crisis regions in 1933 that presumably improved more than the average until 1936. Thus, the higher was the unemployment in 1933 the smaller was the increase in mortality. ${ }^{36}$ The regression analysis indicates that mortality did, in fact, increase most in the large industrial cities and in those coastal regions of the Northwest that depended heavily on imported protein. That holds true even after controlling for changes in fertility, age structure, and unemployment. 


\section{Conclusion}

We conclude that an autarchy policy was, indeed, highly detrimental to the health in an industrialized food-importing economy. Price and quantity regulations did not alleviate the situation, at least not for people living in large cities. We compare trends in mortality and nutritional status with other living standard indicators for the Weimar Republic (1919-1933) and for the early years of the Nationalist Socialist regime (1933-1937). The findings reveal a little known fact, that in the mid-1930s mortality rates in Germany increased substantially in almost every age group, even when compared with those in 1932, the worst year of the Great Depression. Moreover, children's heights — an indicator for health and quality of nutritionwere generally stagnating between 1933 and 1938, but had increased significantly during the 1920s. Persecution alone cannot explain such an acute crisis in biological well-being; the nonpersecuted segments of the German population were affected as well. Rearmament expenditures increased at the expense of public health measures. Food imports were curtailed, and prices of many agricultural products were controlled. There is ample evidence that this set of policies had an adverse effect on the nutritional status and the health of the German population. Specifically, suffering most from the policy of restricting imports of protein-rich agricultural products were the highly developed regions with large urban sectors and the coastal regions of the Northwest.

The economic policy of the National Socialists is often considered the one policy area in which they were successful (for a textbook exposition, see Hildebrand 1989). The popular impression is based on the drastic reduction of unemployment that had been extremely high during the Great Depression. ${ }^{37}$ Totalitarian governments can reduce unemployment through public works projects and massive military spending, as well as stimulate profit expectations of industrialists within the framework of an imminent armament boom. Buchheim showed that Germany's recovery had actually started before Hitler's economic policy could have had an effect (except a psychological one that influenced expectations) (Abelshauser, 1999, pp. 503-538; Buchheim, 2001). Yet, the image of the Nazis ending unemployment is still dominating the popular view of German living standards in the 1930s. A discussion of the biological components of those standards is relevant and necessary to fundamentally change that impression. In sum, if biological aspects are taken into consideration, the Nazi economic policy was - in contrast to popular view — not successful in raising the welfare of the majority of the German population during the early years of the regime. Rather, it produced a majo crisis in health and mortality. 


\section{References}

Abelshauser, W., 1999, Kriegswirtschaft und Wirtschaftswunder. Deutschlands wirtschaftliche Mobilisierung für den Zweiten Weltkrieg und die Folgen für die Nachkriegszeit. Vierteljahreshefte für Zeitgeschichte 47, 503-538.

Baten, J., 2000, Height and Real Wages: An International Overview. Jahrbuch für Wirtschaftsgeschichte 2000-1, 17-32.

Baten, J., 2002, Does Communism and Nationalsocialism Make You Shorter and Die Earlier? Wirtschaftsordnung und Biologischer Lebensstandard In: Denzel, M., Goemmel, R. (Eds.),Weltwirtschaft und Wirtschaftsordnung. Steiner Verlag, Stuttgart (forthcoming).

Blasius, D., 1996, Tuberkulose: Signalkrankheit deutscher Geschichte. Geschichte in Wissenschaft und Unterricht 47, 320 332.

Broszat, M. and E. Froehlich, 1979, Alltag und Widerstand - Bayern im Nationalsozialismus (Piper, München and Wien).

Bry, G., 1960, Wages in Germany (University Press, Princeton).

Buchheim, C., 1994, Zur Natur des Wirtschaftsaufschwungs in der NS-Zeit. In: Buchheim, C. et al. (Eds.), Zerrissene Zwischenkriegszeit. Wirtschaftshistorische Beiträge. Knut Borchardt zum 65.Geburtstag. Nomos-Verlagsgesellschaft, Baden-Baden, pp. 97-119.

Buchheim, C., 2001, Die Wirtschaftsentwicklung im Dritten Reich - mehr Desaster als Wunder. Vierteljahreshefte für Zeitgeschichte 49, 653-664.

Bundesarchiv Berlin NS 5 VI 8983 pp. 51, 52, Der deutsche Volkswirt Nr. 47 vom 25. Aug. 1939.

Corni, G. and H. Gies, 1997, Brot - Butter - Kanonen. Die Ernährungswirtschaft in Deutschland unter der Diktatur Hitlers (Akademie Verlag, Berlin).

Corni, G., 1990, Hitler and the Peasants. Agrarian Policy of the Third Reich, 1930-1939 (Berg, New York et al).

Dasgupta, P., Weale, M., 1992, On Measuring the Quality of Life. World Development 20, 119-131.

Dinkel, R. H., 1985, The seeming paradox of increasing mortality in a highly industrialized nation: the example of the Soviet Union. Population Studies 39-1, 87-97.

Drukker, J. W. and V. Tassenaar, 1997, Paradoxes of Modernization and Material Well-Being in the Netherlands during the Nineteenth Century. In: Steckel, R., Floud, R. (Eds.), Health and Welfare during Industrialisation. The University of Chicago Press, Chicago and London, pp. 331-337.

Dumke, R.,1991, Income inequality and industrialization in Germany, 1850-1913: the Kuznets hypothesis reexamined. In: Brenner, Y.S., et al (Eds.), Income distribution in historical perspective. Cambridge University Press, Cambridge, pp. 117-148.

Franklin, H.L., 1940, Wartime Agriculture and Food Control in Germany. Foreign Agriculture, April 1940, 181-220, cited from Bundesarchiv Berlin NS 5 VI 8983 pp. 17, 18, Hunger in Deutschland? Betrachtung einer Studie Deutschlands Kriegsernährung. Vierteljahreshefte fuer Wirtschaftsforschung 2/3 21.4.41, pp. 158-159.

Floud, R. and B. Harris, 1997, Health, Height and Welfare: Britain, 1700-1900. In: Steckel, R., Floud, R. (Eds.), Health and Welfare during Industrialisation. The University of Chicago Press, Chicago and London, pp. 91-126.

Geyer, M. H., 1989, Soziale Sicherheit und wirtschaftlicher Fortschritt. Überlegungen zum Verhältnis von Arbeitsideologie und Sozialpolitik im ,Dritten Reich'. Geschichte und Gesellschaft 15, 382-406.

Gumpert, M., 1940, Heil Hunger! Health under Hitler. (Allen and Unwin, London).

Gundel, M., 1936, Die aktive Schutzimpfung gegen Diphterie und die Ergebnisse der in den Jahren 1934 und 1935 in Deutschland durchgeführten Diphtherieschutzimpfungen. Veröffentlichungen aus dem Gebiete des Volksgesundheitsdienstes 416, Vol. 475.

Hachtmann, R., 1988, Lebenshaltungskosten und Reallöhne während des Dritten Reichs. Vierteljahrschrift für Sozial- und Wirtschaftsgeschichte 75, 32-73.

Hachtmann, R., 1989, Industriearbeit im Dritten Reich. Untersuchungen zu den Lohn- und Arbeitsbedingungen in Deutschland 1933-1945 (Vandenhoeck \& Ruprecht, Göttingen).

Hammonds, E., 1999, Childhood's deadly scourge. The Campaign to Control Diphtheria in New York City, 1880-1930 (The Johns Hopkins University Press, Baltimore and London).

Hecker, R., 1954, Gesundheitsfürsorge für das Kind im Schulalter. In: Hecker, R. et al (Eds.), Grundriß der Gesundheitsfürsorge, Ernst Reinhardt, München and Basel, pp. 106-117.

Hermanussen, M., 1997, Catch-up in Final Height after Unification of Germany. Acta Med. Auxol. 29,3, 135-141.

Hoffmann, W. G. et al, 1965, Das Wachstum der deutschen Wirtschaft seit der Mitte des 19. Jahrhunderts (Duncker \& Humblot, Berlin et al).

Hinze, S., 1993, „Die ungewöhnlich geduldigen Deutschen“, Arbeiterleben 1934-1936 im Spiegel ausgewählter Gestapodokumente (Regierungsbezirk Potsdam). In: Eichholtz coop with A. Püschel (Eds.), Brandenburg in der NS-Zeit. Studien und Dokumente. Verlag Volk und Welt, Berlin, pp. 32-62.

Hitzler, H., 1952, Der Wirkungskreis der Allgemeinen Ortskrankenkasse im Gesundheitswesen der Stadt Frankfurt am Main in den Jahren 1924 bis 1950, Doctoral thesis, Frankfurt a. Main.

Kater, M., 1989, Doctors under Hitler (The University of North Carolina Press, Chapel Hill and London).

Knödler, U., 1991, Von der Reform zum Raubbau. Arbeitsmedizin, Leistungsmedizin, Kontrollmedizin. In: Frei, N. (Ed.), Medizin und Gesundheitspolitik in der NS-Zeit (Schriftenreihe der Vierteljahrshefte für Zeitgeschichte, Sondernummer). Oldenbourg, München, pp. 113-136.

Komlos, J., 1999, On the Biological Standard of Living in Russia and the Soviet Union. Slavic Review 58,1, 71-79.

Kranig, A., 1992, Arbeitnehmer, Arbeitsbeziehungen und Sozialpolitik unter dem Nationalsozialismus. In: Bracher, K.D. et al. (Eds.), Deutschland 1933-1945. Neue Studien zur nationalsozialistischen Herrschaft. Bundeszentrale für politische Bildung, Bonn, pp. 135-152.

Kümmel, W., 1993, 'Die Ausschaltung' - Wie die Nationalsozialisten die jüdischen und die politisch mißliebigen Ärzte aus dem Beruf verdrängten. In: Blekker, J., Jachertz, N. (Eds.), Medizin im “Dritten Reich”. Deutscher Ärzte-Verlag, Köln, pp. 70-77.

Lewis, J., 1986, The prevention of diphtheria in Canada and Britain 1914-1945. Journal of Social History 20, 163-176. 
Lunn, P.G., 1991, Nutrition, Immunity and Infection. In: Schofield, R. et al. (Eds.), The Decline of Mortality in Europe. Clarendon, Oxford, pp. 131-145.

Marcusson, H., ${ }^{3}$ 1962, Die Gesundheit des Kindes im Vorschulalter (Verlag Volk und Wissen, Berlin).

Maddison, A., 1995, Monitoring the World Economy 1820-1992 (OECD, Paris).

Mason, T., 1977, Sozialpolitik im Dritten Reich. Arbeiterklasse und Volksgemeinschaft (Westdeutscher Verlag, Opladen).

Mironov, B.N., 1999, Tall Requirements and Small Reality. Slavic Review 58, no. 1, 80-90.

Mitchell, B., 1988, British Historical Statistics. (Cambridge University Press, Cambridge et al).

Mitchell, B., 1992, International Historical Statistics: Europe 1750-1988 (MacMillan, Basingstoke).

Morgan, S., 1988, Biological Indicators of Change in the Standard of Living in China During the $20^{\text {th }}$ Century. In: Komlos, J., Baten, J. (Eds.), The Biological Standard of Living in Comparative Perspective. Steiner, Stuttgart, pp. 7-34.

Naumann, K., 1941, Stillhäufigkeit und Stilldauer in einem westdeutschen Landkreis. Der öffentliche Gesundheitsdienst 7 , no. $14,417-421$.

Oppenheimer-Bluhm, H., 1965, The Standard of Living of German Labor under Nazi Rule. New York 1943. Reprint (Kraus, New York).

Overy, R.J., 1994, War and Economy in the Third Reich (Clarendon Press, Oxford).

Petzina, D., 1977, Die deutsche Wirtschaft in der Zwischenkriegszeit (Steiner, Wiesbaden).

Petzina, D. et al., 1978, Sozialgeschichtliches Arbeitsbuch III. Materialien zur Statistik des Deutschen Reichs 1914-1945 (Beck, München).

Pine, L., 1997, Nazi Family Policy 1933-1945 (Berg, Oxford and New York).

Proctor, R., 1999, The Nazi War on Cancer (Princeton University Press, Princeton and New York).

Reichsgesundheitsblatt, various issues.

Riphahn, R., 1999, Die Mortalitätskrise in Ostdeutschland und ihre Reflektion in der Todesursachenstatistik. Zeitschrift für Bevölkerungswissenschaft, 24-3, 329-363.

Ritschl, A. and M. Spoerer., 1997, Das Bruttosozialprodukt in Deutschland nach den amtlichen Volkseinkommens- und Sozialproduktsstatistiken 1901-1995. Jahrbuch für Wirtschaftsgeschichte 2, 27-54.

Sachße, C. and F. Tennstedt, 1992, Der Wohlfahrtsstaat im Nationalsozialismus. Geschichte der Armenfürsorge. Vol. 3, (W. Kohlhammer, Stuttgart et al).

Seidlmayer, H., 1937, Geburtenzahl, Säuglingssterblichkeit und Stillung in München in den letzten 50 Jahren. Doctoral thesis, München.

Siegel, T., 1982, Lohnpolitik im nationalsozialistischen Deutschland. In: Sachse, C. et al. (Eds.), Angst, Belohnung, Zucht und Ordnung. Herrschaftsmechanismen im Nationalsozialismus. Westdeutscher Verlag, Opladen, pp. 54-139.

Silverman, D., 1988, National Socialist Economics: the Wirtschaftswunder Reconsidered. In: Eichengreen, B., Hatton, T. (Eds.), Interwar Unemployment in International Perspective. Kluwer Academics Publishers, Dordrecht, pp. 185-220.

Spree, R., 1992, Der Rückzug des Todes. Der Epidemiologische Übergang in Deutschland während des 19. und 20. Jahrhunderts (Universitätsverlag, Konstanz).

Statistik des Deutschen Reichs, various issues.

Statistik der Bundesrepublik Deutschland, Vol. 62.

Statistische Jahrbücher of various German cities.

Statistisches Bundesamt Wiesbaden (Ed.), 1972, Bevölkerung und Wirtschaft. 1872-1972 (Kohlhammer, Stuttgart and Mainz).

Statistisches Jahrbuch für das Deutsche Reich, various issues.

Statistisches Jahrbuch für die Bundesrepublik Deutschland, various issues.

Süß, W., 1998a, Gesundheitspolitik. In: Hockerts, H.G. (Ed.), Drei Wege deutscher Sozialstaatlichkeit. NS-Dikatur, Bundesrepublik und DDR im Vergleich (Schriftenreihe der Vierteljahreshefte für Zeitgeschichte 76). Oldenbourg, München, pp. 55-99.

Süß, W., 1998b, Krieg und Gesundheitspolitik im nationalsozialistischen Deutschland 1939-1945. Unpubliched doctoral thesis, München.

Szerreiks, 1939, Über Ergebnisse von Röntgenreihenuntersuchungen in ihrer Beziehung zur D.B.-Frage bei Lungentuberkulose. Veröffentlichungen aus dem Gebiete des Heeres-Sanitätswesens 108, 72-126.

Tanner, J.M., ${ }^{2} 1990$, Foetus into Man: Physical Growth from Conception to Maturity (Harvard University Press, Cambridge).

Tanner, J.M., 1994, Introduction: Growth in Height as a Mirror of the Standard of Living, In: Komlos, J. (Ed.), Stature, Living Standards an Economic Development. Essays in Anthropometric History. The University Chicago Press, Chicago and London, pp.1-6.

Tennstedt, F., 1976, Sozialgeschichte der Sozialversicherung. In: Blohmke, M. et al. (Eds.), Sozialmedizin in der Praxis (Handbuch der Sozialmedizin, Vol. 3). Enke, Stuttgart, pp. 385-492.

The Registrar-General's Statistical Review of England and Wales of the Year 1938, 1940, Majesty's Stationery Office, London.

Van der Bussche, H., 1993, Ärztliche Ausbildung und medizinische Studienreform im Nationalsozialismus. In: Blekker, J., Jachertz, N. (Eds.), Medizin im “Dritten Reich”. Deutscher Ärzte-Verlag, Köln, pp. 117-128.

Vierteljahreshefte zur Statistik des Deutschen Reichs, 1938.

U.S. Department of Commerce, 1975, Historical Statistics of the United States from Colonial Times to 1970, Part 1. (GPO, Washington D.C).

Von der Decken, H., 1937/38, Die Ernährung in England und Deutschland. Vierteljahrshefte zur Wirtschaftsforschung 12 , 177-199.

Von der Lippe, P. 1996, Die politische Rolle der amtlichen Statistik in der ehemaligen DDR. Jahrbücher für Nationalökonomie und Statistik, 215-6, 641-673.

Wagner, A., 2002, Ein Human Development Index für Deutschland. Die Entwicklung des Lebensstandards von 1920 bis 1960. Jahrbuch fuer Wirtschaftsgeschichte, (forthcoming).

Werner, W.F., 1983, Bleib übrig! Deutsche Arbeiter in der nationalsozialistischen Kriegswirtschaft (Schwann, Düsseldorf). 
Wheatcroft, S.G., 1999, The Great Leap Upwards: Anthropometric Data and Indicators of Crises and Secular Change in Soviet Welfare Levels, 1880-1960. Slavic Review 58, no. 1, 27-60.

Wu, J., 1992, The Anthropometric History of Pittsburgh and Allegheny County, Pennsylvania, 1890-1945. Annals of Human Biology 19, 79-86.

\section{Endnotes}

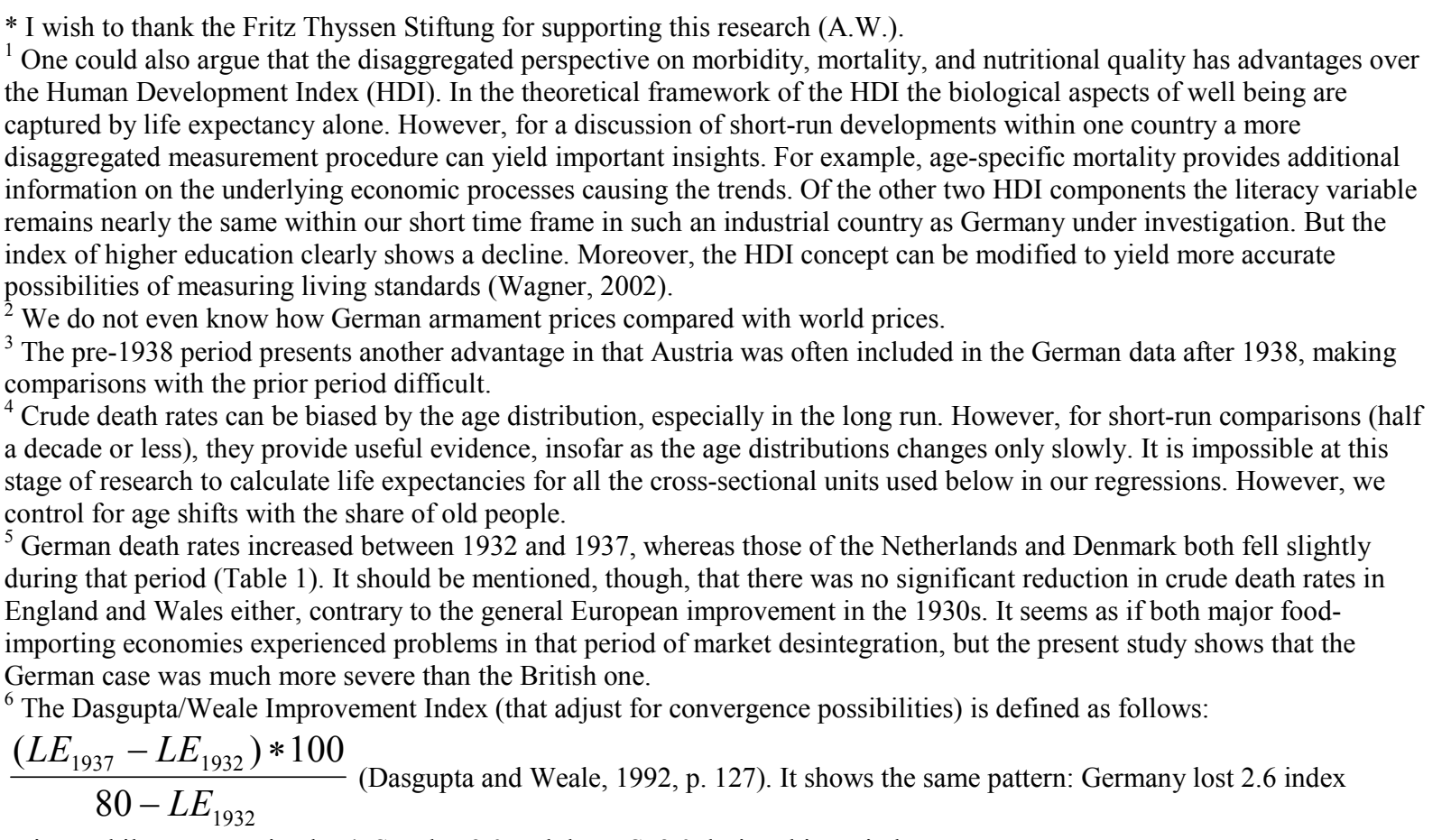
points, while France gained 7.4, Sweden 3.0 and the U.S. 3.0 during this period.

${ }^{7}$ Data on heights are astonishingly scarce for early- $20^{\text {th }}$-century Germany. The military compiled height data but with long interruptions, and few records survive. Our nationwide research among German archives indicates that measurements in prisons stopped around 1900, but that, while measurements in schools probably continued to be taken, the records are missing. There are, nevertheless, several published series of height measurements that are reliable, thanks to contemporary anthropologists who recorded them, among them Erich Koch of the University of Jena. In Leipzig the height series continuous up to 1953. The 1947 hunger is plainly visible, and the recovery after 1948 is striking, demonstrating that children's heights react very quickly both to adverse and to positive conditions. This makes the reasoning unlikely that the 1933-38 crises may have been caused by a carry-over-effect from the Great Depression.

${ }^{8}$ Heights of adults that were organized by birth cohorts.

${ }^{9}$ The question whether economic change can cause mortality increase in industrial nations was answered positively in the debate about the mortality increase in the Soviet Union of the 1980s and 1990s, and the mortality increase among East German older men in the 1990s. Note however, that completely different models apply to those situations in which the mortality increase was caused by a transition to a different economic system (see Dinkel, 1985 and Riphahn, 1999). ${ }^{10}$ Hachtmann (1988) suggested that the official cost of living index not be used. He argues that it understates real price increases, because of shortages and/or quality deterioration in certain consumer goods, hidden inflation, housing shortages, and so on. Recent research by André Steiner und Christoph Buchheim confirms this view. Hachtmann considers a figure that was mentioned in an unofficial document to be more reliable. In addition, he calculated the allowance for increased compulsory or quasi-compulsory levies. On the other hand, even if we would allow the cumulative inflation in food prices to be two to three times higher than the official index indicates, we would still not obtain stagnating wage levels. As a first check, note that wholesale prices of foodstuffs increased by $24 \%$ from 1933 to 1938 , while the CPI reports only a $7 \%$ cumulative increase in the same category. Arguably, wholesale prices (WPI) were politically less visible and their statistics less likely to be rigged than the CPI series. Using the WPI deflator for foodstuffs to deflate wages would thus decrease real wages by two thirds. The compulsory deductions included contributions to social insurance institutions and direct taxes such as income and citizen taxes. Voluntary contributions embraced regular contributions to the Party, the Labour Front, the "Peoples's Welfare," and other public or semi-public organisations (Oppenheimer-Bluhm, 1965, pp. 20, 23; Siegel, 1982, p. 105; Hachtmann, 1988, pp. 34-47).

${ }^{11}$ Even if not everyone would accept the decrease in unemployment between 1932 to 1935 at face value. Silverman (1988) expressed doubts about the Nazi statistics but did not estimate the degree of falsification (see also Buchheim, 1994).

${ }^{12}$ Lower unemployment tends to lead to a higher propensity to claim insurance payments, whereas higher unemployment often makes people go to work even if they are not feeling well. Moreover, more people in a poor health status are employed in a full-employment economy than during a period of high unemployment.

${ }^{13}$ For example, the number of physicians published in Statistische Jahrbücher differs from those compiled by the medical bureaucracy (Kater, 1989, p. 267). Similarly, the health companies' expenditures on medical treatments are slightly inconsistent. They vary among publications, because the types of health insurance companies included varied.

${ }^{14}$ For the number of hospital beds and their number of patients see also Sachße and Tennstedt (1992), p. 176, Tab. 2.18. 
${ }^{15}$ Despite that considerable loss, a substantial supply shortage was not openly discussed before the beginning of the war. However, it should be borne in mind that the consequence of outlawing Jewish or politically suspect doctors from the profession may have been more severe at the local level. The number of Frankfurt's local health insurance doctors (AOK Frankfurt) decreased from 455 to fewer than 350 between 1932 and 1938 (Hitzler, 1952, p. 19). In addition, the deterioration of the general health situation may have increased demand and caused a marked decline in the doctor-patient ratio (Kater, 1989, p. 41).

${ }^{16}$ Changes in the medical curriculum also had an adverse impact on the training of doctors. Traditional medical subjects were abridged to make room for such fields as race hygienics (e.g., Kater, 1989, pp. 46172, 174; Van der Bussche, 1993, pp. 117128).

${ }^{17}$ On a local level, the nominal expenditure for medical treatments per member of the Frankfurt's local health insurance company (AOK Frankfurt) increased after the Depression, but it did not recover to the levels of the late 1920s (Hitzler, 1952, p. 19).

${ }_{18}$ The numbers were 1930: 89,613, 1931: 43,367, 1932: 8,584, 1933: 7,186, 1934: 12,087, 1935: 24,374, 1936: 27,014, 1937 : 27,000. The slight recovery in these numbers after 1934 was due to the Law for the Prevention of Hereditarily Diseased Offspring from July 141933 because costs for these measures were recorded under the title "illness prevention and recovery measures".

${ }^{19}$ But totalitarian regimes are also good at short-circuiting public lobbying for social benefits - which often leads to suboptimal outcomes.

${ }^{20}$ This does not include deaths caused by congenital malformations. Infant mortality from congenital malformations may have increased because those infants were neglected or killed. However, it could also be that more diseases were recorded under that category. This pattern of change in causes of death reflects the ambiguous character of Nazi population policy: while it tried to "eliminate" those who were taken as "racially and hereditarily inferior," it supported those who were seen as both "hereditarily healthy and productive" members of the society.

${ }^{21}$ Most efforts were directed towards schoolchildren through health supervision including medical, dental, and orthopaedic inspection, physical education, control of infectious diseases in schools, sanitation of school premises, supervision as well as recuperation measures of sick children, education about genetics and racial hygiene (Hecker, 1954, pp. 110-117. Sachße and Tennstedt, 1992, pp. 168-169).

${ }^{22}$ Some American cities such as New York successfully conducted vaccination programmes against diphtheria before the 1930s (Hammonds, 1999).

${ }^{23}$ Contemporaries were aware of the higher German morbidity rates from diphtheria than in other countries (Gumpert, 1940, p. 56; Gundel, 1936, p. 14.)

${ }_{24}$ Standardised mortality rates were calculated because diseases affect people differently depending on their age. The standardised death rates used represent the mortality of the inhabitants in the various years, assuming the structure of the population at risk was the same as that of the year 1925 .

${ }_{25}$ Earlier diagnoses improved the chances of cure (Blasius, 1996, p. 330-331). The prompt identification of potential carriers of the TB bacillus became also progressively more necessary because of the new collective National socialists mass organisations (Sachse and Tennstedt, 1992, p. 170). Thus mass screening was prevelant in the army. In Königsberg, all new recruits doing compulsory military service were X-rayed by the fall of 1935 . The number of people X-rayed increased considerably under the Nazis (Proctor, 1999, p. 87-88. Szerreiks, 1939, p.74). By 1937, tuberculosis welfare centres administered 1.5 million X-rays in the Reich (Sachße and Tennstedt, 1992, p. 170).

${ }^{26}$ Applying the model of the epidemiological transition, Spree (1992) argued that the transitional phase (the age of declining epidemics) ended after the First World War and the so-called age of degenerative and man-made diseases started in Germany. Thus, the period under investigation belongs to phase three of the epidemiological transition and should be characterised by an increasing importance of cancer and diseases of the heart and circulatory system.

${ }^{27}$ The comparison of cause-specific crude death rates between Germany and England \& Wales is somewhat distorted because of the differences of the population at risk between Germany and England \& Wales. Yet, the age structure of the population of both countries was fairly similar in the early 1930s.

Age-structure of the population (in \% of the total population), Germany (1933) and England \& Wales (1931).

\begin{tabular}{llllllll}
\hline & $0-5$ & $5-14$ & $15-29$ & $30-44$ & $45-59$ & $60-69$ & $>70$ \\
\hline Germany & 7.8 & 16.0 & 26.9 & 22.3 & 16.6 & 6.9 & 3.8 \\
England \& Wales & 7.5 & 16.3 & 25.7 & 21.3 & 17.5 & 7.3 & 4.2 \\
\hline
\end{tabular}

Source: Derived from Statistisches Jahrbuch des Deutschen Reich (various issues); Mitchell, 1988, p.15.

${ }^{28}$ In fact, protein consumption per capita (meat, milk, and eggs) was higher in England than in Germany in the mid-1930s (Von der Decken, 1937/38, pp. 178-179).

${ }^{29}$ The desire for protein by the human organism is not overwhelmingly strong: one does not necessarily experience a feeling of starvation when proteins are missing from the diet.

${ }^{30}$ Not all currencies were convertible, as large share of Germany's trade were channelled into bilateral clearing arrangements; Germany's disappointing export performance also had to do with its default of 1933.

${ }^{31}$ Other regional differences stem from the possibilities to increase local protein production. For example, in Thuringia protein consumption was increased, whereas in Hesse, with its traditionally high protein production, there were no suitable factor inputs left to increase protein production. In Mecklenburg there was an increase in non-market consumption (meat and milk that was previously bought on markets, but subsequently were purchased directly from the farmers) that did keep the prices within bounds.

${ }_{32}$ Hinze (1993), reports on the year 1935 that beef, pork and fat is not available. Source: LB Stapo 6/1935 Auszug aus folgenden Archivalien GStA, Nr. 2,4, Bl. 29, p. 54, and "....the population receives generally in the cities of my county not enough pork, and not enough fat originating from cattle and pigs, because of insufficient supply. A strong under-supply of all necessary fats characterizes human nutrition.... butter is not available, not even in the large cities....RP 6.10.1935", there are 
fights in the streets and panic purchases take place: "... the butter- and meat scarcity leads to and "excellent" spirit in the streets. Some women became violent against Nazi supporters, who tried to excuse the scarcity.... I was in various department stores, and saw how women were carried away, who had passed out after waiting for hours to buy $1 / 16$ pound of utter or $1 / 4$ pound of peanut butter...LB der KPD, 20.12.1935.

${ }^{33}$ In addition, consumption of some important goods even declined drastically at the national level, such as eggs (because of declining imports). And, even if it is true that imports were increasing from the low of the Great Depression, they were certainly not increasing as strongly as in other countries (and as expected from the income increase).

${ }^{34}$ Of course, lobbies tend to complain when there is an expectation that political powers will provide subsidies, so complaints do not inform us about the price that would have prevailed without the price control system, or without autarky: Corni reports complaints about the incomes of farmers that decreased each year relative to other social groups. (It might have declined anyway) (Corni, 1990, p. 104). Their complaints about low prices are numerous. Consumers on the other hand were also dissatisfied, because of the rising prices. (They might have risen more without price controls).

${ }^{35}$ If the price of beef was allowed to move, how was it possible that a maximum price of cattle is mentioned in the sources? The answer is that the system of „Spannenpreise“ (scope prices) that allowed the beef price to move within a boundary, but not beyond a maximum price.

${ }^{36}$ Is there evidence that the increase in diphtheria was related to malnutrition? We ran separate regressions - that are not shown here, but are available from the authors - on the rate of diphtheria increase. It was also strongly influenced by the protein scarcity indicator (purchasing power of beef). We explored whether lack of physicians could have contributed to regional diphtheria increase. However, the sign of the variable „,increase in physicians per capita“ is positive and significant. This suggests that causality ran the other way around: increases in diphtheria lead health authorities to increase the number of physicians per capita in the regions most affected.

${ }^{37}$ The Austrian populist politician, Joerg Haider, has become infamous with his statement, that Hitler had "a proper employment policy" (eine ordentliche Beschäftigungspolitik). 


\section{CESifo Working Paper Series}

(for full list see www.cesifo.de)

732 Yu-Fu Chen and Michael Funke, Working Time and Employment under Uncertainty, May 2002

733 Kjell Erik Lommerud, Odd Rune Straume, and Lars Sørgard, Downstream Merger with Oligopolistic Input Suppliers, May 2002

734 Saku Aura, Does the Balance of Power Within a Family Matter? The Case of the Retirement Equity Act, May 2002

735 Sandro Brusco and Fausto Panunzi, Reallocation of Corporate Resources and Managerial Incentives in Internal Capital Markets, May 2002

736 Stefan Napel and Mika Widgrén, Strategic Power Revisited, May 2002

737 Martin W. Cripps, Godfrey Keller, and Sven Rady, Strategic Experimentation: The Case of Poisson Bandits, May 2002

738 Pierre André Chiappori and Bernard Salanié, Testing Contract Theory: A Survey of Some Recent Work, June 2002

739 Robert J. Gary-Bobo and Sophie Larribeau, A Structural Econometric Model of Price Discrimination in the Mortgage Lending Industry, June 2002

740 Laurent Linnemer, When Backward Integration by a Dominant Firm Improves Welfare, June 2002

741 Gebhard Kirchgässner and Friedrich Schneider, On the Political Economy of Environmental Policy, June 2002

742 Christian Keuschnigg and Soren Bo Nielsen, Start-ups, Venture Capitalits, and the Capital Gains Tax, June 2002

743 Robert Fenge, Silke Uebelmesser, and Martin Werding, Second-best Properties of Implicit Social Security Taxes: Theory and Evidence, June 2002

744 Wendell Fleming and Jerome Stein, Stochastic Optimal Control, International Finance and Debt, June 2002

745 Gene M. Grossman, The Distribution of Talent and the Pattern and Consequences of International Trade, June 2002

746 Oleksiy Ivaschenko, Growth and Inequality: Evidence from Transitional Economies, June 2002

747 Burkhard Heer, Should Unemployment Benefits be Related to Previous Earnings?, July 2002 
748 Bas van Aarle, Giovanni Di Bartolomeo, Jacob Engwerda, and Joseph Plasmans, Staying Together or Breaking Apart: Policy-makers' Endogenous Coalitions Formation in the European Economic and Monetary Union, July 2002

749 Hans Gersbach, Democratic Mechanisms: Double Majority Rules and Flexible Agenda Costs, July 2002

750 Bruno S. Frey and Stephan Meier, Pro-Social Behavior, Reciprocity or Both?, July 2002

751 Jonas Agell and Helge Bennmarker, Wage Policy and Endogenous Wage Rigidity: A Representative View From the Inside, July 2002

752 Edward Castronova, On Virtual Economies, July 2002

753 Rebecca M. Blank, U.S. Welfare Reform: What's Relevant for Europe?, July 2002

754 Ruslan Lukach and Joseph Plasmans, Measuring Knowledge Spillovers Using Patent Citations: Evidence from the Belgian Firm's Data, July 2002

755 Aaron Tornell and Frank Westermann, Boom-Bust Cycles in Middle Income Countries: Facts and Explanation, July 2002

756 Jan K. Brueckner, Internalization of Airport Congestion: A Network Analysis, July 2002

757 Lawrence M. Kahn, The Impact of Wage-Setting Institutions on the Incidence of Public Employment in the OECD: 1960-98, July 2002

758 Sijbren Cnossen, Tax Policy in the European Union, August 2002

759 Chandima Mendis, External Shocks and Banking Crises in Developing Countries: Does the Exchange Rate Regime Matter?, August 2002

760 Bruno S. Frey and Lars P. Feld, Deterrence and Morale in Taxation: An Empirical Analysis, August 2002

761 Lars Calmfors and Åsa Johansson, Nominal Wage Flexibility, Wage Indexation and Monetary Union, August 2002

762 Alexander R. W. Robson and Stergios Skaperdas, Costly Enforcement of Property Rights and the Coase Theorem, August 2002

763 Horst Raff, Preferential Trade Agreements and Tax Competition for Foreign Direct Investment, August 2002

764 Alex Cukierman and V. Anton Muscatelli, Do Central Banks have Precautionary Demands for Expansions and for Price Stability? - Theory and Evidence, August 2002

765 Giovanni Peri, Knowledge Flows and Knowledge Externalities, August 2002

766 Daniel Friedman and Nirvikar Singh, Equilibrium Vengeance, August 2002 
767 Sam Bucovetsky and Michael Smart, The Efficiency Consequences of Local Revenue Equalization: Tax Competition and Tax Distortions, August 2002

768 Tapio Palokangas, International Labour Market Regulation and Economic Growth with Creative Destruction, August 2002

769 Rudi Dornbusch, The New International Architecture, September 2002

770 Hans-Werner Sinn, Weber's Law and the Biological Evolution of Risk Preferences: The Selective Dominance of the Logarithmic Utility Function, September 2002

771 Thomas Mayer, The Macroeconomic Loss Function: A Critical Note, September 2002

772 Seppo Honkapohja and Kaushik Mitra, Learning Stability in Economies with Heterogenous Agents, September 2002

773 David Laidler, Inflation Targets Versus International Monetary Integration - A Canadian Perspective, September 2002

774 Morten I. Lau, Panu Poutvaara, and Andreas Wagener, The Dynamic Cost of the Draft, September 2002

775 Steven Brakman, Harry Garretsen, and Charles van Marrewijk, Locational Competition and Agglomeration: The Role of Government Spending, September 2002

776 Anke S. Kessler and Christoph Lülfesmann, The Theory of Human Capital Revisited: On the Interaction of General and Specific Investments, September 2002

777 Kjell Erik Lommerud, Frode Meland and Lars Sørgard, Unionized Oligopoly, Trade Liberalization and Location Choice, September 2002

778 Antonio Merlo and François Ortalo-Magné, Bargaining over Residential Real Estate: Evidence from England, September 2002

$779 \mathrm{Yu}-\mathrm{Fu}$ Chen and Michael Funke, Exchange Rate Uncertainty and Labour Market Adjustment under Fixed and Flexible Exchange Rates, September 2002

780 Michael S. Michael, International Migration, Income Taxes and Transfers: A Welfare Analysis, September 2002

781 Clemens Fuest and Alfons Weichenrieder, Tax Competition and Profit Shifting: On the Relationship between Personal and Corporate Tax Rates, October 2002

782 Jan Bouckaert and Hans Degryse, Softening Competition by Enhancing Entry: An Example from the Banking Industry, October 2002

783 Johann K. Brunner and Susanne Pech, Adverse Selection in the Annuity Market with Sequential and Simultaneous Insurance Demand, October 2002

784 Gregory D. Hess and Eduard Pelz, The Economic Welfare Cost of Conflict: An Empirical Assessment, October 2002 
785 Jan Erik Askildsen, Uwe Jirjahn, and Stephen C. Smith, Works Councils and Environmental Investment: Theory and Evidence from German Panel Data, October 2002

786 Geir H. Bjønnes, Dagfinn Rime, and Haakon O. Aa. Solheim, Volume and Volatility in the FX-Market: Does it matter who you are?, October 2002

787 John Evans and John Fingleton, Entry Regulation and the Influence of an Incumbent Special Interest Group, October 2002

788 Wolfgang Ochel, International Comparisons and Transfer of Labour Market Institutions, October 2002

789 B. Gabriela Mundaca, Moral Hazard Effects of Bailing out under Asymmetric Information, October 2002

790 Gene M. Grossman and Edwin L.-C. Lai, International Protection of Intellectual Property, October 2002

791 John Hassler, José V. Rodriguez Mora, Kjetil Storesletten, and Fabrizio Zilibotti, A Positive Theory of Geographic Mobility and Social Insurance, October 2002

792 Paul De Grauwe and Marianna Grimaldi, The Exchange Rate in a Model with Heterogeneous Agents and Transactions Costs, October 2002

793 Guido Friebel and Mariassunta Giannetti, Fighting for Talent: Risk-shifting, Corporate Volatility, and Organizational Change, October 2002

794 Jan Erik Askildsen, Badi H. Baltagi, and Tor Helge Holmås, Will Increased Wages Reduce Shortage of Nurses? A Panel Data Analysis of Nurses' Labour Supply, October 2002

795 Marko Köthenbürger and Panu Poutvaara, Social Security Reform and Intergenerational Trade: Is there Scope for a Pareto-Improvement?, October 2002

796 Paul De Grauwe and Laura Rinaldi, A Model of the Card Payment System and the Interchange Fee, October 2002

797 Volker Böhm and Tomoo Kikuchi, Dynamics of Endogenous Business Cycles and Exchange Rate Volatility, October 2002

798 Mariam Camarero, Javier Ordóñez, and Cecilio Tamarit, The Euro-Dollar Exchange Rate: Is it Fundamental?, October 2002

799 Misa Tanaka, How Do Bank Capital and Capital Adequacy Regulation Affect the Monetary Transmission Mechanism?, October 2002

800 Jörg Baten and Andrea Wagner, Autarchy, Market Disintegration, and Health: The Mortality and Nutritional Crisis in Nazi Germany, 1933-1937, October 2002 